\title{
Pharaoh and Temple Building in the Fourth Century BCE*
}

\author{
Martina Minas-Nerpel
}

1

\section{Introduction}

The fourth century BCE was a period of widespread transformation, marked by the transition from the Oriental empires to the Hellenistic states, in which Egypt played a central role. After the first Persian Period $(525-404 / 1)$, the Twenty-eighth (405/401-399) and Twenty-ninth Dynasties (399-380) were short-lived and seem to have been undermined by competition for the throne. ${ }^{1}$ The rulers were also struggling to repel Persian invasions. It is therefore not astonishing that there are very few traces of temple building or decoration from this short period, which might nonetheless have paved the way for further developments. ${ }^{2}$ According to Neal Spencer, significant temple building was probably planned in the Twenty-ninth Dynasty, but there is no way to prove this. He suggests that much of the cultural renaissance which is attested for the Thirtieth Dynasty may "represent a flourishing of trends nascent in the previous dynasty". ${ }^{3}$

Nectanebo I Nekhetnebef $(380-362)$ and Nectanebo II Nekhethorheb $(360-$ 342 ) of the Thirtieth Dynasty were the last great native pharaohs of Egypt.

* I am most grateful to Paul McKechnie and Jennifer A. Cromwell for the invitation to a very stimulating conference, to John Baines for reading a draft of the chapter and his valuable critical remarks, to Francisco Bosch-Puche for sending me his articles on Alexander ("The Egyptian Royal Titulary of Alexander the Great" I and II) before publication, to Dietrich Raue for information on Heliopolis, to Daniela Rosenow for fig. 5.3, and to Troy L. Sagrillo for fig. 5.5.

1 All dates according to von Beckerath, Handbuch der ägyptischen Königsnamen. For the historical background, see Ruzicka, Trouble in the West: Egypt and the Persian Empire, 35-48.

2 Collected by Kienitz, Politische Geschichte Ägyptens, 122-123; Traunecker, “Essai sur l' histoire de la XXIX ${ }^{e}$ Dynastie", 407-419; Arnold, Temples of the Last Pharaohs, 99-105; Blöbaum, "Denn ich bin ein König ...", 347-350; see also Phillips, Columns of Egypt, 157-158 and fig. 306-307. For the context, see Myśliwiec, Twilight of Ancient Egypt, 158-176, and Ladynin “Late Dynastic Period".

3 Spencer, A Naos of Nekhthorheb, 47 . 
Nectanebo I, a general from Sebennytos in the Delta, usurped the throne from Nepherites II, the last king of the Twenty-ninth Dynasty, and was crowned king of Egypt at Sais, the former capital city of the Twenty-sixth Dynasty in the western Delta. ${ }^{4}$ The key political event in his eighteen-year reign was the defeat of the Persian forces attempting to invade Egypt in 373. For Egypt, Nectanebo I began a period of great prosperity, which is reflected in massive temple construction, from the first cataract region to the Delta, as well as in the oases of the western desert (for details, see below). His co-regent for two years and successor, Teos (or Tachos; $364 / 62-360$ ), moved into Palestine; but soon, in 36 o, his nephew Nectanebo II was placed on the throne. Nectanebo II continued the building activity on a large scale. The Thirtieth Dynasty left an impressive legacy of temple construction at the major sites of Egypt, so that the sacred landscape changed considerably and with long-lasting effects. ${ }^{5}$ This legacy also demonstrates the economic effectiveness of the Thirtieth Dynasty. Nectanebo II, the last native pharaoh, repelled a Persian invasion in 350 and ruled until 342, when Artaxerxes III conquered Egypt and the second Persian Period of Egypt began.

In the turmoil of the second Persian Period from 343 to 332 , no temple seems to have been built; at least, nothing has been found so far. Unfinished building projects of the Thirtieth Dynasty were only completed after the liberation from the Persians, mainly in the early Ptolemaic period.

With the victories of Alexander the Great, the Persian Empire disintegrated, and he took the land by the Nile without resistance. ${ }^{6}$ Under his reign, Egyptian temples were extended and decorated at crucial points (see below). Although his two Macedonian successors never visited Egypt - neither his brother Philip Arrhidaios nor his son Alexander IV - their cartouches can be found on some Egyptian monuments, which suggests that the building projects continued,

4 Nectanebo I took the throne name Kheperkara (von Beckerath, Handbuch der ägyptischen Königsnamen, 226-227), which refers back to Senwosret I of the Twelfth Dynasty. It seems that he wanted to evoke the grandeur of his predecessors, referring to a time before the Persian rulers conquered Egypt. Artistic traditions of the Twenty-sixth Dynasty were taken up again and developed (Spencer, $A$ Naos of Nekhthorheb, 47).

5 For collections of data and short discussions of the construction programmes of the Thirtieth Dynasty, see Blöbaum, "Denn ich bin ein König ...", 351-360; Jenni, Die Dekoration des Chnumtempels, 87-100; Spencer, A Naos of Nekhthorheb, 47-52. For the historical background, see also Ruzicka, Trouble in the West: Egypt and the Persian Empire, 145-198.

6 Hölbl, History of the Ptolemaic Empire, 9-12, 77-8o. Chauveau, "L'Égypte en transition", discusses the transition of Egypt from Persian to Macedonian rulers. See also Ruzicka, Trouble in the West: Egypt and the Persian Empire, 199-209. 
probably under some influence from Ptolemy the Satrap, who ruled Egypt de facto as absolute autocrat.

The Ptolemies carried to fruition the political aspiration of the Thirtieth Dynasty, the creation of a once more powerful Egyptian empire that dominated the Eastern Mediterranean for a time. Large new temples were built and unfinished sacred projects were completed. Ptolemy I Soter, following Alexander's example, recognized temple building as a critical element in Egyptian kingship and engaged with it, perhaps not on the same scale as his son and successor Ptolemy $1 \mathrm{I},{ }^{7}$ but quite noticeably.

This essay does not present a complete list of temple building sites in Egypt of the fourth century $\mathrm{BCE}$, but rather concentrates on some major sites where temple construction was undertaken, looking into specific features that were developed and asking why and how far sacred landscapes in Egypt changed in this period of transition under the last native pharaohs, Alexander, and his immediate successors including Ptolemy I Soter, as well as reflecting on possible (cross-) cultural relevance, especially for the usurpers and/or foreign rulers of the period.

When looking at the sites, we need to bear in mind that only a small proportion of ancient temples is preserved, due to the normal reuse of older temples as building material during antiquity and subsequent periods, the burning of stone for lime, earthquakes, and other factors that changed the landscape substantially, not only for modern visitors but already in antiquity. This is especially true for sites in the Delta, a bias that considerably distorts our picture of the construction programmes. Before exploring specific sites and their temple buildings, I give a short description of the Egyptian temple as the reflection of the cosmos, in order to outline the religious and cultural basis on which these temples were built.

7 Ptolemy II Philadelphos' building programme has never been discussed in a dedicated publication, as has been done for Ptolemy I Soter (Swinnen, "Sur la politique religieuse de Ptolémée Ier”), Ptolemy vi Philometor and Ptolemy viII Euergetes II (Minas, "Die Dekorationstätigkeit", 1 and 2), and Ptolemy IX Soter II and Ptolemy x Alexander I (Caßor-Pfeiffer, "Zur Reflexion ptolemäischer Geschichte", 1 and 2). Chauveau, "L'Égypte en transition", 390-395, and Blöbaum, "Denn ich bin ein König ...", 361-363, and Ladynin “The Argeadai building program in Egypt", 223-228, present lists of attestations for the Macedonian rulers Alexander the Great, Philip Arrhidaios, and Alexander IV; see Bosch-Puche ("Egyptian Royal Titulary of Alexander the Great", I and II) for Alexander the Great. 
Temples are amongst the most striking elements in the ancient Egyptian civilisation, from the Old Kingdom to the Roman era. The temples of the GraecoRoman period include some of the best-preserved examples of religious architecture and texts from antiquity. King and temple-or in modern terms, state and church—should not be seen as in opposition, ${ }^{8}$ since "both kingship and temple were brought to life, sustained and celebrated in the central highcultural products of Egyptian civilization". 9

Cosmological associations vouchsafed the integrity of the temple, which served as an image of the world. ${ }^{10}$ Every single temple mirrored the cosmos and was a microcosm in itself, as well as the earthly residence of its main deity. The ancient Egyptians re-enacted creation by ceremonially founding and constructing a temple, and in the process re-establishing maat (universal order). As part of this cosmic meaning, the daily repetition of the solar cycle was represented in the temple. The inner sanctuary symbolizes the primeval mound of earth that emerged from Nun, the marshy waters at creation. The cosmic dimension of the temple is further reflected in the depiction of the ceiling as sky, the plant decoration on the base of the wall, and the columns of the pillared halls, which have the forms of aquatic plants. In the Graeco-Roman period they often have composite capitals, which bring together different vegetal elements and also form a point of contact with Hellenistic architecture. ${ }^{11}$

The ritual scenes show two categories of protagonists involved, one or several deities and the pharaoh in traditional Egyptian regalia, no matter whether it was a native or a foreign king. It was a requirement of temple decoration to show the pharaoh performing the rituals that would guarantee the existence of Egypt. The king presents diverse offerings, ranging from real objects, such as food, flowers, or amulets, to symbolic acts like smiting the enemies or presenting maat..$^{12}$ Further topics of the temple decoration included festivals, foundation, and protection of the temple and its gods, in accordance with the theological system of each temple.

8 As, for example, by Huß, Der makedonische König.

9 Baines, "Temples as Symbols", 216.

10 Hornung, Idea into Image, 115-129. For a detailed study, based on the temple of Horus at Edfu, see Finnestadt, Image of the World.

11 McKenzie, Architecture of Alexandria and Egypt, 122-132. Graefe, "Die Deutung der sogenannten 'Opfergaben”. 
With the temples, the cosmic cycle was extended into history. ${ }^{13}$ The kings could be presented as the sons and successors of the creator gods, eternally re-enacting creation, thus fulfilling maat and protecting Egypt. Since the temple reflects the entire cosmos and functions according to the same principles, constructing temples was a way to demonstrate and to reaffirm the royal status. This was especially important for usurpers and foreign rulers, who were keen to be legitimized. Even if the rulers of the Twenty-eighth to the Thirtieth Dynasty were considered as native pharaohs, ${ }^{14}$ they were usurpers, and needed to be legitimized in their role as pharaoh, as did Alexander and the Ptolemies.

The Egyptian temples of the Hellenistic period are the principal surviving monuments of the Ptolemies in the country, so it seems obvious that these rulers attached great importance to these enormous buildings. Yet, these foreign rulers probably knew little of their symbolism, and they could not read their inscriptions. The Egyptian elite must have stimulated the building and decoration policy, since their life focused around the temples, which were fundamental to native Egyptian culture. ${ }^{15}$ It is therefore not surprising that, from the very beginning of their rule in Egypt, the Ptolemaic rulers supported the Egyptian sacred complexes and initiated a gigantic programme of temple construction and decoration, thus securing maat and the support of the native priesthood. This policy is already attested on the Satrap Stele, dating to 311 , when Ptolemy son of Lagos was not yet ruling over Egypt as king, but only as governor for Alexander IV. Ptolemy confirms a donation of land to the gods of Buto and therefore obtains their support and that of their priests (see further section 4$)^{16}$

13 Assmann, "Der Tempel der ägyptischen Spätzeit", 14.

14 According to Assmann, Herrschaft und Heil, 237, the Libyan (Twenty-second and Twentythird) and Kushite (Twenty-fifth) Dynasties were not perceived as foreign rulers, only the Persian and Greek. Vittmann, Ägypten und die Fremden, 141-142, considers Amyrtaios, the sole ruler of the Twenty-eighth Dynasty, of Libyan origin, but calls the rulers of the Twentyninth and Thirtieth Dynasties the last native pharaohs, except for ephemeral local kings. Even if some might regard the rulers of the Twenty-sixth and Twenty-eighth to Thirtieth Dynasties as foreigners (see, for example, Jansen-Winkeln, "Die Fremdherrschaften in Ägypten”, 18), it is irrelevant to their roles as kings. For usurpers, foreign kings, and their choice of legitimizing royal names in the Late Period, see Kahl, "Zu den Namen spätzeitlicher Usurpatoren".

15 Baines, "Temples as Symbols", 216, 231. See also Minas-Nerpel, "Egyptian Temples of the Roman Period".

16 For the text of the Satrap Stele, see Sethe, Hieroglyphische Urkunden der griechisch-römischen Zeit (=Urk. II), 11-22. For a photograph, see Kamal, Stèles ptolémaiques et romaines. 


\subsection{The Nile Delta}

Under the kings of the Twenty-sixth Dynasty, many temples were constructed at Sais and elsewhere in the Delta, ${ }^{17}$ but not much survives. After the interruption of the first Persian rule and the short-reigning Twenty-eighth and Twenty-ninth Dynasties, the kings of the Thirtieth Dynasty took up temple building where the Twenty-sixth Dynasty had left off and started some grand new projects, many of which were completed or extended by the early Ptolemaic rulers.

\subsubsection{Sebennytos and Behbeit el-Hagar}

Sebennytos, modern Samannud, is in the centre of the Delta and was the capital of the Twelfth nome of Lower Egypt (see Figure 5.1). As the home of the Thirtieth Dynasty kings, it was a powerful city, where much temple construction was undertaken; but the site is heavily ruined. A temple for Onuris might have existed there in the Saite period, ${ }^{18}$ but the earliest surviving architectural remains of a large temple date to the reign of Nectanebo II. The majority of the dated reliefs bear the names of Philip Arrhidaios, Alexander IV, Ptolemy II, and Ptolemy X Alexander II. ${ }^{19}$ Two naoi of Nectanebo II were dedicated to Onuris-Shu, which together with other remains points to a major temple of the Thirtieth Dynasty that was further extended in the Macedonian and Ptolemaic periods.

In antiquity, a legend developed around the completion of the temple of Onuris-Shu, Egyptian Per-Shu, in Greek Phersos. Onuris appeared in Nectanebo's dream, complaining to Isis that his temple had not yet been finished. When Nectanebo II woke up, he immediately sent for the high priest and arranged for the decoration to be completed. This narrative, of clear Egyptian origin, is only attested in a Greek translation, ${ }^{20}$ except for a few small Demotic fragments,

II, pl. LVI (CGC 22182). New translation, commentary, and analysis: Schäfer, Makedonische Pharaonen. See also Ockinga's contribution in this volume. El-Sayed, Documents relatifs à Sais.

Spencer, "Temple of Onuris-Shu", 7.

19 Arnold, Temples of the Last Pharaohs, 127-128, 140-141, 158. Spencer, "Temple of OnurisShu", 7-8.

20 Attested on the Greek manuscript P.Leiden I 396, see Gauger, "Traum des Nektanebos", 189-219, esp. 196, col. III, 6-15: "Ich [Onuris] bin nun außerhalb meines eigenen Tempels und das Werk im Allerheiligsten ist nur halbvollendet wegen der Schlechtigkeit des Tempelvorstehers. Die Herrscherin der Götter hörte die Worte, antwortete aber nichts. Als 


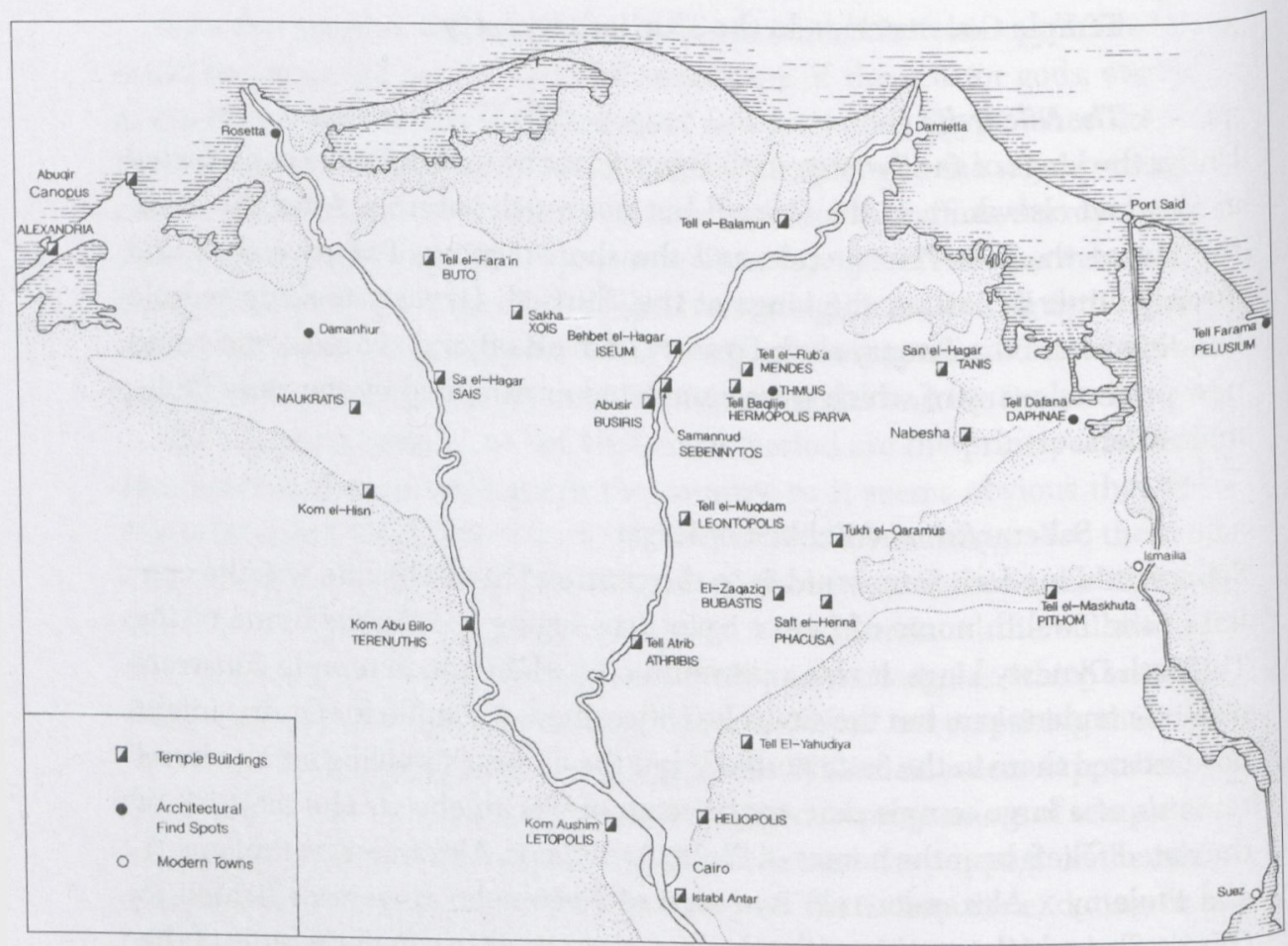

FIGURE 5.1 Map of the Nile Delta

AFTER ARNOLD, TEMPLES OF THE LAST PHARAOHS, FIG. XVI ON P. 20

which contain either some words of Nectanebo's dream or excerpts from the beginning of its sequel. ${ }^{21}$

Already in the time of Piye of the Twenty-fifth Dynasty, Behbeit el-Hagar began to rival Sebennytos. ${ }^{22}$ The once large, but now completely ruined, temple of Isis and the family of Osiris at Behbeit el-Hagar is located just to the north of the powerful city Sebennytos (Figures 5.1 and 5.2 ).

The history of the place is poorly known, but the first mention of Per-hebit is not earlier than the reign of Amenhotep III of the Eighteenth Dynasty. ${ }^{23}$ The Iseum, situated near the modern village, was uniquely constructed entirely of hard stone, but earthquakes heavily damaged the site, and agriculture as well

(Nektanebos) den Traum sah, erwachte er und befahl eilend zu schicken nach Sebennytos zum Hohenpriester und zum Propheten des Osnuris." See also Huß, Der makedonische König, 133-134 (with further references), and below section 4 with note 102. Ryholt, "Nectanebo's Dream", 222, 225-228.

22 Bianchi, "Sebennytos", 766.

23 Favard-Meeks, "Temple of Behbeit el-Hagara", 102; and "Behbeit el-Hagar", 174. 


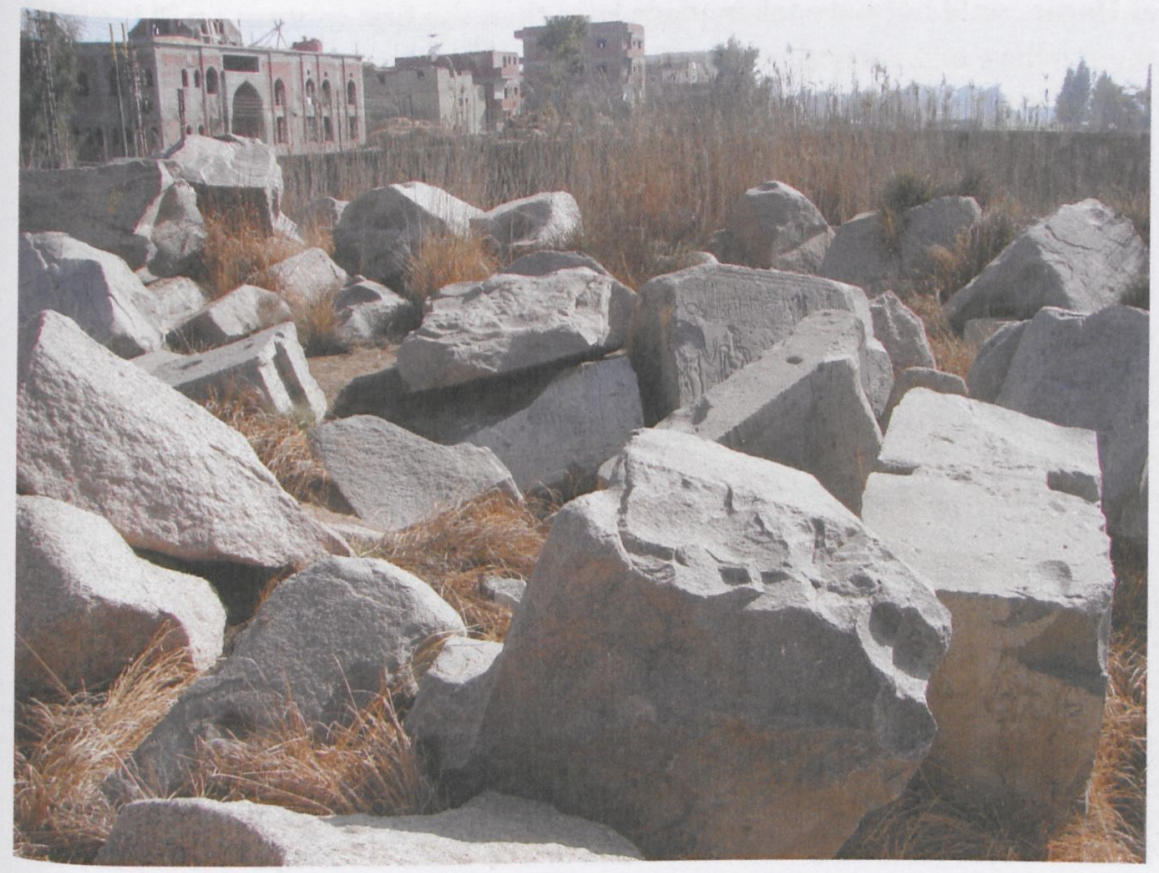

FIGURE 5.2 Ruins of the Iseum at Behbeit el-Hagar

PHOTOGRAPH: AUTHOR

as a cemetery gradually encroached on the precinct. More than half of the archaeological area has now been lost. ${ }^{24}$ Inside the temenos wall, which still survives on three sides, is a big mound of huge and small granite blocks, so entangled that a plan is difficult to propose and must remain hypothetical. ${ }^{25}$ A dromos can be distinguished, with one sphinx surviving. It leads to a temple façade, followed by columned hall and the sanctuary of Isis, a goddess whose cult was much promoted in the Thirtieth Dynasty. Behind the sanctuary are chapels dedicated to cults of various aspects of Osiris. The presence of a huge staircase suggests that some of the Osirian chapels were located on the roof, a characteristic feature of late Egyptian temples.

Since a block of this temple was reused in a temple dedicated to Isis and Serapis in Rome, either at the time of its first foundation in 43 ВСE or when renovated under Domitian (AD81-96), the collapse of the temple at Behbeit

24 Favard-Meeks, "Temple of Behbeit el-Hagara", 102; and "Present State of the Site of Behbeit el-Hagar", 31.

25 For a plan with a hypothetical suggested layout, see Favard-Meeks, "Temple of Behbeit el-Hagara", 102; 105, fig. 2. 
el-Hagar could not have taken place later than the first century AD. ${ }^{26}$ It seems then to have been abandoned and used as a quarry.

The temple had been dedicated under Nectanebo II, but there is evidence that its construction was planned already under Nectanebo $\mathrm{I}^{27} \mathrm{On}$ the surviving reliefs, the names of Nectanebo II and those of Ptolemy II Philadelphos and Ptolemy III Euergetes are well attested, but not of Ptolemy I Soter. ${ }^{28}$ This covers a period of construction and decoration of roughly 140 years, from 360 to $221 \mathrm{BCE}$. According to textual information, it is fairly certain that the last kings of the Twenty-sixth Dynasty undertook earlier temple construction at this site. ${ }^{29}$

\subsubsection{Bubastis}

Another important location for the Thirtieth Dynasty is Bubastis, a city in the eastern Delta. The ruins of the ancient town Per-Bastet, now Tell Basta, ${ }^{30}$ where the goddess Bastet was venerated as described by Herodotus (II 138), are increasingly threatened by the modern city of Zagazig. Although monuments from all ancient Egyptian periods are attested, ${ }^{31}$ Bubastis probably gained its greatest importance in the Twenty-second Dynasty, the Libyan period, when it was the royal residence. The vast ruins of Tell Basta encompass today around seventy hectares, dominated by the main temple, roughly $220 \times 70 \mathrm{~m}$, littered

26 Favard-Meeks, "Present State of the Site of Behbeit el-Hagar", 33.

27 Favard-Meeks, "Temple of Behbeit el-Hagara", 103. For the constructions under Nectanebo II, see Favard-Meeks, "Les constructions de Nectanébo II à Behbeit el-Hagara".

The name of Ptolemy I might have been attested somewhere else in the now destroyed buildings. Swinnen, "Sur la politique religieuse de Ptolémée Ier", 118, connected cautiously a naos found at Mit Ghamr (see Habachi, "Notes on the Delta Hermopolis", 458-461), inscribed with Soter's cartouches, with Behbeit el-Hagar, although the findspot is rather closer to Tell el-Moqdam ( $11 \mathrm{~km}$ distance), ancient Leontopolis (Gomaà, "Tell el-Moqdam", 351); see fig. 5.1 for a map of the Delta. The naos is dedicated to Isis and Osiris, who are both mistress and master of a place called Djehuty, which might be connected to Behbeit elHagar (see Zivie, "A propos du toponyme $d b t$ ", 206-207). Mit Ghamr is also not far from Hermopolis Parva, which was the capital of the Fifteenth Lower Egyptian nome, where only a mound of huge red and black granite blocks remains of the main temple of Thoth, which in the Thirtieth Dynasty probably extended or replaced the Twenty-sixth Dynasty temple (Arnold, Temples of the Last Pharaohs, 108).

29 Favard-Meeks, "Temple of Behbeit el-Hagara", 103; and "Behbeit el-Hagar", 174.

30 Leclère, Villes de basse Égypte, vol. 1, 363-391.

31 Spencer, $A$ Naos of Nekhthorheb, 39; Rosenow, "Great Temple of Bastet", 11. Leclère, Villes de basse Égypte, vol. 1, 117. 


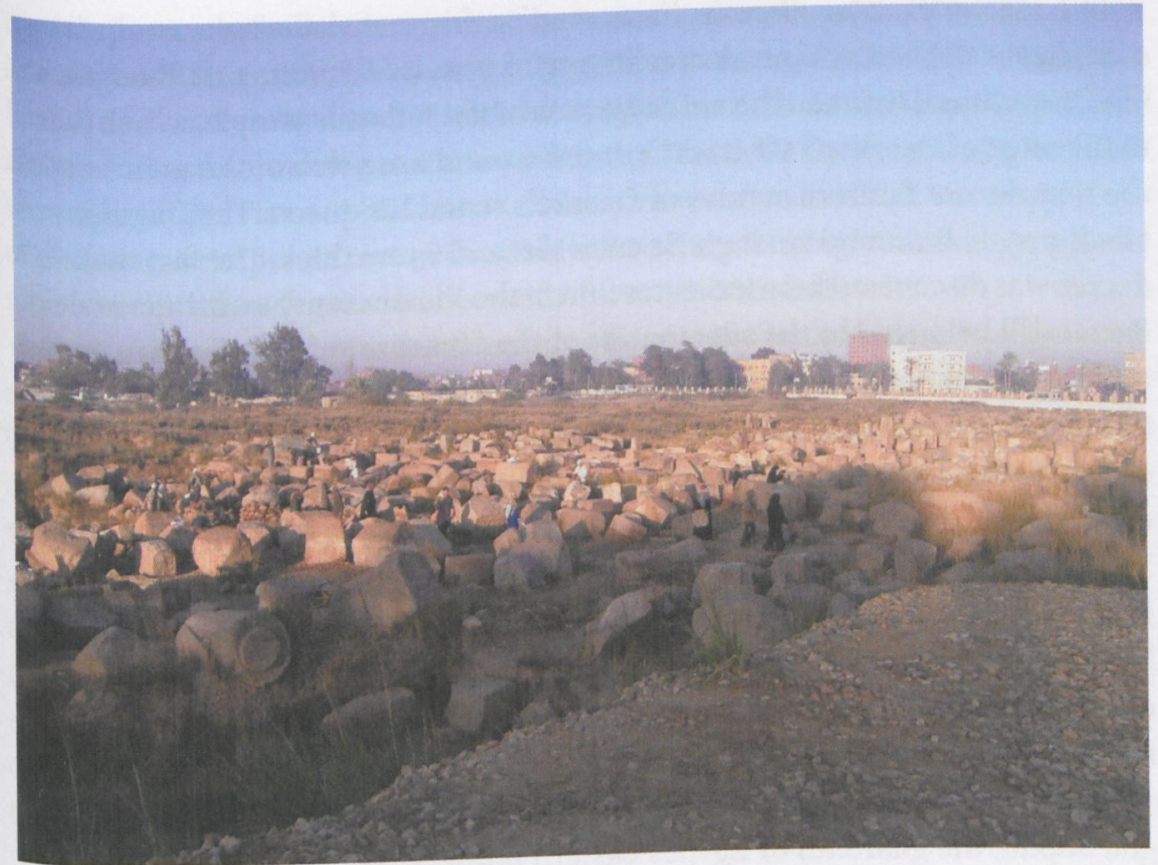

FIGURE 5.3 Ruins of the temple at Bubastis

PHOTOGRAPH: DANIELA ROSENOW

with more than 4000 stone fragments, mainly of red granite. ${ }^{32}$ As at Behbeit elHagar, the visitor to the temple today sees only a large area of blocks and broken monuments, due to an earthquake probably around 2000 years ago (Figure 5.3).

The late temple was begun in the Twenty-second Dynasty under Osorkon I and extended significantly under Osorkon $\mathrm{II},{ }^{33}$ with further work being undertaken by Nectanebo II. In his reign, a separate hall of roughly $60 \times 60 \mathrm{~m}$ was constructed in the westernmost area, where a number of shrines were situated. ${ }^{34}$ Fragments of at least eight huge naoi for secondary deities were arranged around the red granite naos of Bastet.

Tietze, "Neues Exemplar des Kanopus-Dekrets", 3. Since 1991, archaeological and epigraphic fieldwork has been undertaken by the Tell Basta Project, which is a joint mission of the University of Potsdam/Germany, the Egyptian Supreme Council, and the Egypt Exploration Society. Spencer, A Naos of Nekhthorheb, 40; Arnold, Temples of the Last Pharaohs, 129. Rosenow, Das Tempelhaus des Großen Bastet-Tempels; Rosenow, "Great Temple of Bastet", 12; "Nekhethorheb Temple", 43. See plan in Spencer, A Naos of Nekhthorheb, 91, figs. 2223. At present, it is not known exactly how the Thirtieth Dynasty building related to, or 
In 2004, an exciting discovery was made: a fragment of a stele, comprising a duplicate of the Canopus decree dating to year 9 of Ptolemy III Euergetes I (238), was found in situ in the entrance area of the Bubastis temple, which dates to the reign of Osorkon $\mathrm{II}^{35}$ It was located around $2 \mathrm{~m}$ north of the main axis of the temple, not far from statues of Osorkon II and his queen. The fragment of black granite is around $1 \mathrm{~m}$ high, $84 \mathrm{~cm}$ wide, and $65 \mathrm{~cm}$ thick. The fact that this decree was discovered here indicates that in the third century BCE the temple of Bastet still belonged to the sanctuaries of the first three categories mentioned in the last line of each version of the text. ${ }^{36}$ So far, no other trace of Ptolemaic activity has been found at Bubastis. Furthermore, this is the first time that the exact original location within a temple of one of the synodal decrees has been established.

\subsubsection{Saft el-Henna}

Not far from Bubastis, roughly $10 \mathrm{~km}$ east of Zagazig, Saft el-Henna is located, ancient Per-Sopdu, where Nectanebo I had begun a temple of which only traces survive. The presence of a stele of Ptolemy II suggests that the site was still important in the Ptolemaic Period. ${ }^{37}$ The temple was dedicated to the falcongod Sopdu, the guardian of Egypt's eastern borders. Again, several monolithic naoi are known to come from this location, all dating to Nectanebo $\mathrm{I}^{38}$

A naos is the ritual heart of a temple, a shrine in the most sacred location, in which the image of the principal deity was placed-or those of further gods also venerated there. Because it is monolithic hard stone, it formed the most powerful level of protection ${ }^{39}$ of the (wooden) statue within. This might be

was incorporated into, the Twenty-second Dynasty structures. The remains could be seen as replacing or extending an existing building or as a completely new temple (Spencer, $A$ Naos of Nekhthorheb, 39-42; Rosenow, "Nektanebos-Tempel", "Sanctuaire de Nectanebo II", and "Nekhethorheb Temple"). See Tietze et al., "Ein neues Exemplar des Kanopus-Dekrets", 1-29, for an archaeological report on the find and the edition of the texts.

36 Pfeiffer, Dekret von Kanopos, 65, 194-197.

37 Arnold, Temples of the Last Pharaohs, 130.

38 Gomaà, "Saft el-Henna", 351-352; Virenque, "Les quatre Naos de Saft el-Henneh", 19-28. First: the so-called naos of Sopdu (CGC 70021); second: the naos found in el-Arish, but originally from Saft el-Henna, now in the Ismailia Museum (no. 2248); third: fragments of a naos of Shu found in several places in the Delta, including site $\mathrm{T}$ at Abuqir by Goddio and his team, now in the Louvre D 37 and in Alexandria JE 25774 (see Leitz, Altägyptische Sternuhren, 3-57; Goddio and Clauss, Egypt's Sunken Treasures, no. 31-34, pp. 46-53. See the edition in von Bomhard, Naos of the Decades); and fourth: a naos of Tefnut.

39 Spencer, A Naos of Nekhthorheb, 50. Virenque, "Les quatre Naos de Saft el-Henneh", 27, calls these naoi from Saft el-Henna "fortresses miniature". 
especially true in Saft el-Henna, which was in the first line of any possible Asian invasion and thus strategically vital. The Delta in particular needed to be reinforced against Persian attacks, and this might also be a reason why the eastern Delta received so much attention under the Thirtieth Dynasty, if the view of strategic support is correct. One might also view the monolithic naoi as pieces of extravagant expenditure on the gods rather than "strategic" buildings, which were specifically safeguarded because of worries about security.

Naoi not only displayed the theology of a specific temple: their inscriptions also legitimized the Thirtieth Dynasty rulers, connecting them to the gods. ${ }^{40}$ This legitimation was of utmost importance in a period when Egypt was so often threatened by Persian invasions. In addition, Nectanebo I had usurped the throne of Egypt and needed to prove his legitimacy, which is one probable reason behind his vast building programme. ${ }^{41} \mathrm{~A}$ political meaning can thus be attributed to the religious texts on the naoi. The shrines of Saft el-Henna are cultic instruments intended to protect the kings magically and to legitimize their rule against obstacles whether political or metaphysical. This profusion of monolithic naoi is not attested from earlier periods and seems to be specific to the Thirtieth Dynasty. ${ }^{42}$

\subsubsection{Naukratis and Thonis-Herakleion}

The emporium of Naukratis, situated on the east bank of the now vanished Canopic branch of the Nile, some $80 \mathrm{~km}$ south-east of Alexandria and around $15 \mathrm{~km}$ from Sais, was established in the late seventh century BCE, and was in existence until at least the seventh century AD. ${ }^{43}$ It functioned as the port of the Twenty-sixth Dynasty royal city of Sais and remained a busy centre of industry

40 Schneider, "Mythos und Zeitgeschichte", 207-242: in the case of the el-Arish naos, the king was connected to Shu and Geb.

41 See Schneider, "Mythos und Zeitgeschichte”, 207-242 (esp. 242), and Rondot, "Une monographie bubastite", 249-270 (esp. 270), who have put this in context in their examinations of naoi from Saft el-Henna and Bubastis.

Spencer, A Naos of Nekhthorheb, 64-65, appendix 4, provides a list of Thirtieth Dynasty temple naoi, altogether thirty-six, of which two thirds (twenty-four) come from the Delta, one third (twelve) from Bubastis alone. Klotz, "Naos of Nectanebo I" adds another one of Nectanebo I from Sohag, Gabra, "Ein vergessener Naos Nektanebos I", yet a further one, now housed in Old Cairo in the entry area of the Coptic Museum. See Thiers, "Naos de Ptolémée II Philadelphe", 259-265, for a list of monolithic royal naoi from Pepi I to the Roman period.

43 Ancient Naukratis has been a focus of interdisciplinary research at the British Museum for several years, see Thomas and Villing, "Naukratis revisited 2012", 81-125. While Naukratis was chosen as a trade centre for the Greeks in Egypt, an Egyptian town must have already 
and a thriving emporium as well as a locus of cross-cultural exchange for much of its history. ${ }^{44}$ In the Thirtieth Dynasty, it was the chief Greek town in Egypt and a flourishing trading post.

Naukratis contained several temples of Greek gods, as well as a monumental Egyptian temple, but hardly anything can be seen there today. ${ }^{45}$ The Naukratis Stele of Nectanebo I, now in the Egyptian Museum in Cairo, was found 1899 in the temple precinct. It is a round-topped, finely carved stele of black granite, almost $2 \mathrm{~m}$ high and $88 \mathrm{~cm}$ wide. ${ }^{46}$ In the lunette, under the winged sun disk, Nectanebo I is shown presenting offerings to the enthroned goddess Neith in two almost symmetrical scenes. ${ }^{47}$ Below is the inscription in fourteen columns, dated to the king's year 1 ( $38 \mathrm{O} \mathrm{BCE}) .{ }^{48}$ The stele's main pragmatic content is that the king's decree granted the temple one-tenth of the revenue derived from the seaborne imports that were subjected to custom tax, plus one-tenth of the revenue obtained from the tax on locally manufactured goods. ${ }^{49}$ By dedicating the stele with the decree inscribed, the perpetual donation is consecrated and the king's devotion to the goddess displayed.

In 2000 , Franck Goddio's underwater mission succeeded in identifying the site of Thonis-Herakleion in the Bay of Abukir: not only the city itself, but also the harbour and the main Egyptian temple of Amun-Gereb. In May 2001, Goddio's team discovered at Thonis-Herakleion a stele of Nectanebo I, a perfect duplicate of the Naukratis Stele. ${ }^{50}$ Not only the material and dimensions, but also the images and the texts are identical, except for one difference: the name of the city, where the stelae - and hence the decree of Sais - should be placed, was changed, providing the full original designation of Thonis-Herakleion. ${ }^{51}$ The composition and excellent craftsmanship of the stelae demonstrate that

existed there, see Leclère, Villes de basse Égypte, vol. 1, 117; Yoyotte, "L'Amon de Naukratis", 129-136; Yoyotte, Histoire, géographie et religion de l'Égypte ancienne, esp. chapters 45-47.

44 Pfeiffer, "Naukratis, Heracleion-Thonis and Alexandria". For the economic background, see Möller, Naukratis.

45 Spencer, "Egyptian Temple and Settlement at Naukratis", 31-43.

46 For the dimension and the summary of the find circumstances, see von Bomhard, Decree of Saïs, $5-7,15$. See von Bomhard, Decree of Saïs, 16-21 (figs. 2.2-2.9), 29-47, for an analysis of the iconography and its symbolism.

48 For the translations, see the new edition by von Bomhard, Decree of Saïs. See also Lichtheim, Ancient Egyptian Literature III, 86-89.

49 Col. 8-12, see von Bomhard, Decree of Saïs, 72-84. For a comparative study of both stelae and an analysis of both the inscriptions and the iconography, see von Bomhard, Decree of Saïs.

$5^{1}$ Col. 13-14, see von Bomhard, Decree of Saïs, 86-88; Yoyotte, "Le second affichage", 320. 
they were produced by one of the best workshops of the period. The sophisticated language and the allusions to the mythical role and importance of Neith suggest that a priest of her temple at Sais probably drafted the text. The temple depended on income from Naukratis and Thonis and their trade, since they were Egypt's main trading posts on the Mediterranean at that time. Nectanebo I promulgated the decree in his first year of reign, specifying his decision to increase the share of royal revenues which was allocated to the temple of Neith at Sais. After the foundation of Alexandria and the subsequent development of its port, which transformed the Mediterranean metropolis into the greatest emporium of the ancient world, Thonis-Herakleion declined, but the trade and business of the Greeks of Naukratis continued to increase under the Ptolemies. ${ }^{52}$

The discovery of the Thonis and the Naukratis Stelae is quite extraordinary: two identical versions of the same decree, connecting two cities, preserved intact on both sites, both copies found in situ where they had been set up in the Thirtieth Dynasty. They provide important insights, not only into the temples and their economic significance, but also into the communication between the pharaoh and the temple, the state and its subjects, the divine and the human world. The audience was not the Greek-speaking population of the sites at Naukratis and Thonis. Thus, it was not necessary to create bilingual decrees, at least for this purpose. Both stelae were set up to render the royal decree sacred and to immortalize Nectanebo's recognition by "his mother", the goddess Neith, so that she would protect his kingship. The king repays her by caring for her temples and cults. The Sais decree captures the building work of Nectanebo I and the gift in return by the gods of Egypt skilfully: ${ }^{53}$

Just-hearted on the path of god, he [Nectanebo I] is the one who builds their ${ }^{54}$ temples, the one who perfects their wall, who supplies the offering tablet, who multiplies the requirements of the rites, who procures oblation of all kind. Unique god of multiple qualities, it is for him that work

52 Von Bomhard, Decree of Saïs, 114 (with further references).

53 Decree of Sais, col. 5-6; translation by von Bomhard, Decree of Saïs, 66-68.

54 The singular "god" (wz.t ntr "path of god") is followed by a plural resumptive pronoun ( $h w . w t=s n$ "their temples"). The alteration of singular and plural is a very interesting point and should be noted in discussions whether there was a single god. See, for example, Assmann, Moses the Egyptian, 168-207, especially his chapter "Conceiving the One in Ancient Egyptian Tradition", and Baines, "Presenting and Discussing Deities" (with further references). 
the rays of the disk, it is to him that the mountains offer what they contain, that the sea gives its flow ...

\subsection{Heliopolis}

The ancient site of Heliopolis, city of the sun-god and one of the most important religious and intellectual centres of ancient Egypt, is located at the northeastern edge of Cairo. Occupied since predynastic times with extensive building programmes during the dynastic periods, especially the Middle and New Kingdoms, it is almost completely destroyed today. Its landscape and architectural layout is often based on decontextualized objects, since the temenos was robbed of its monuments in the later periods of ancient Egyptian history in order to embellish other places, such as Alexandria; other buildings were subsequently reused for the construction of medieval Cairo. The growing modern suburbs of Matariya, Ain Shams, and Arab el-Hisn with their house constructions and modern garbage dumps threaten most of the remaining structures of ancient Heliopolis. A circular structure in the eastern section of the temenos, about $400 \mathrm{~m}$ in diameter, is the most remarkable remain within the temple area. The function, date, and architectural context of the so-called "High Sand of Heliopolis" is unclear and under investigation of an Egyptian-German archaeological mission. ${ }^{55}$

The temple area of Heliopolis was enclosed by two parallel courses of mud brick walls of different dates, measuring about $1100 \mathrm{~m}$ east to west and $900 \mathrm{~m}$ north to south. According to Dietrich Raue, the outer wall dates to the Thirtieth Dynasty. The original height of no less than $20 \mathrm{~m}$ is estimated on the basis of contemporary constructions at Karnak and Elkab (see below 3.3 and 3.4). ${ }^{56}$ In spring 2015, the Egyptian-German mission discovered several basalt blocks depicting a geographic procession, which once belonged to the soubassement decoration of a hitherto unknown temple of Nectanebo I. ${ }^{57}$ Considering the

See Ashmawy and Raue, "The Temple of Heliopolis: Excavations 2012-14", 8-11; and "Report on the Work of the Egyptian-German Mission at Matariya/ Heliopolis in Spring 2012"; Ashmawy, Beiersdorf, and Raue, "The Thirtieth Dynasty in the Temple of Heliopolis", 13-16. For Heliopolis in general see also Raue, Heliopolis und das Haus des Re.

56 Ashmawy et al., "Report on the Work of the Egyptian-German Mission at Matariya/ Heliopolis in Spring 2014", 19-21 (with figs. 13-15): section 4: "The Enclosure Walls of Heliopolis". I am very grateful to D. Raue for sharing his information on Heliopolis with me in May 2015.

Ashmawy, Beiersdorf, and Raue, "Report on the Work of the Egyptian-German Mission at Matariya/ Heliopolis in Spring 2015", 5-6 (with fig. 5). 
importance of Heliopolis as a cult centre, it does not surprise that the first king of the Thirtieth Dynasty devoted considerable architectural work to this site.

\subsection{The Theban Area}

In the Theban area, large numbers of attestations of the Thirtieth Dynasty survive, ${ }^{58}$ so that I can only mention a few sites. The Bucheum, for example, was created under Nectanebo II, attesting to support of the animal cults which became increasingly popular from the Late Period onwards (see also Tuna elGebel, section 4). From the reign of the last native pharaoh until AD 340, for close to 700 years, the Buchis bulls, a manifestation of Montu, were buried at Armant. ${ }^{59}$

A major undertaking under Nectanebo I was to link the two temple complexes of Luxor and Karnak with a sacred avenue ${ }^{60}$ It was - besides the unfinished first pylon of Karnak, which is very likely to be a Thirtieth Dynasty structure ${ }^{61}$ - the largest project in Thebes by a Thirtieth Dynasty king and has been almost fully excavated in recent years. The paved middle part of the road is $5^{-}$ $6 \mathrm{~m}$ wide and $2 \mathrm{~km}$ long. Both sides are lined by sphinxes, facing the middle of the road (fig. 5.5).

Many sphinx statues from the reign of Nectanebo I have been unearthed, so far numbering far more than a thousand. In addition, the processional way was bordered on the east and west by brick walls, of which almost nothing is left. On the base of one of the sphinxes in the western row, the processional avenue is described: "He [Nectanebo I] built a beautiful road for his father Amun, bordered by walls, planted with trees and decorated with flowers." 62

Arnold, Temples of the Last Pharaohs, 115-119; 131-133.

59 Mond and Myers, Bucheum; Goldbrunner, Buchis. For the Buchis Stele from year 9 of Nectanebo II, see Mond and Myers, Bucheum III, pl. xxxvii.1. For the animal cults under Alexander the Great, also that of Buchis, see Bosch-Puche, "Alejandro Magno y los cultos a animales". For the latest attested Buchis stele, see Mond and Myers, Bucheum III, pl.xlvi.2o (Stele of an unknown emperor); for the date of the stele, see Hölbl, Altägypten im Römischen Reich $1 \mathrm{II}, 44-45$ and fig. 35 : the bull died in year " 57 of Diocletian" (340 CE, under Constantius II; Diocletian died in 313). For further details of the latest attested Buchis stele, see Grenier, “Remarques sur les datations et titulatures", 273-276.

6o Abd el-Razik, Darstellungen und Texte; Cabrol, Les voies processionnelles, 35-37, 145-149, 283-296.

61 Spencer, A Naos of Nekhthorheb, 49 .

62 Translation by Abd el-Razik, Darstellungen und Texte, 157. On a further sphinx, Abd elRazik, Darstellungen und Texte, 157, read: “... a road which he built for his father Amun to celebrate the beautiful feast of procession in Ip.t-Rs.t (Luxor). No road more beautiful has ever existed berore." 


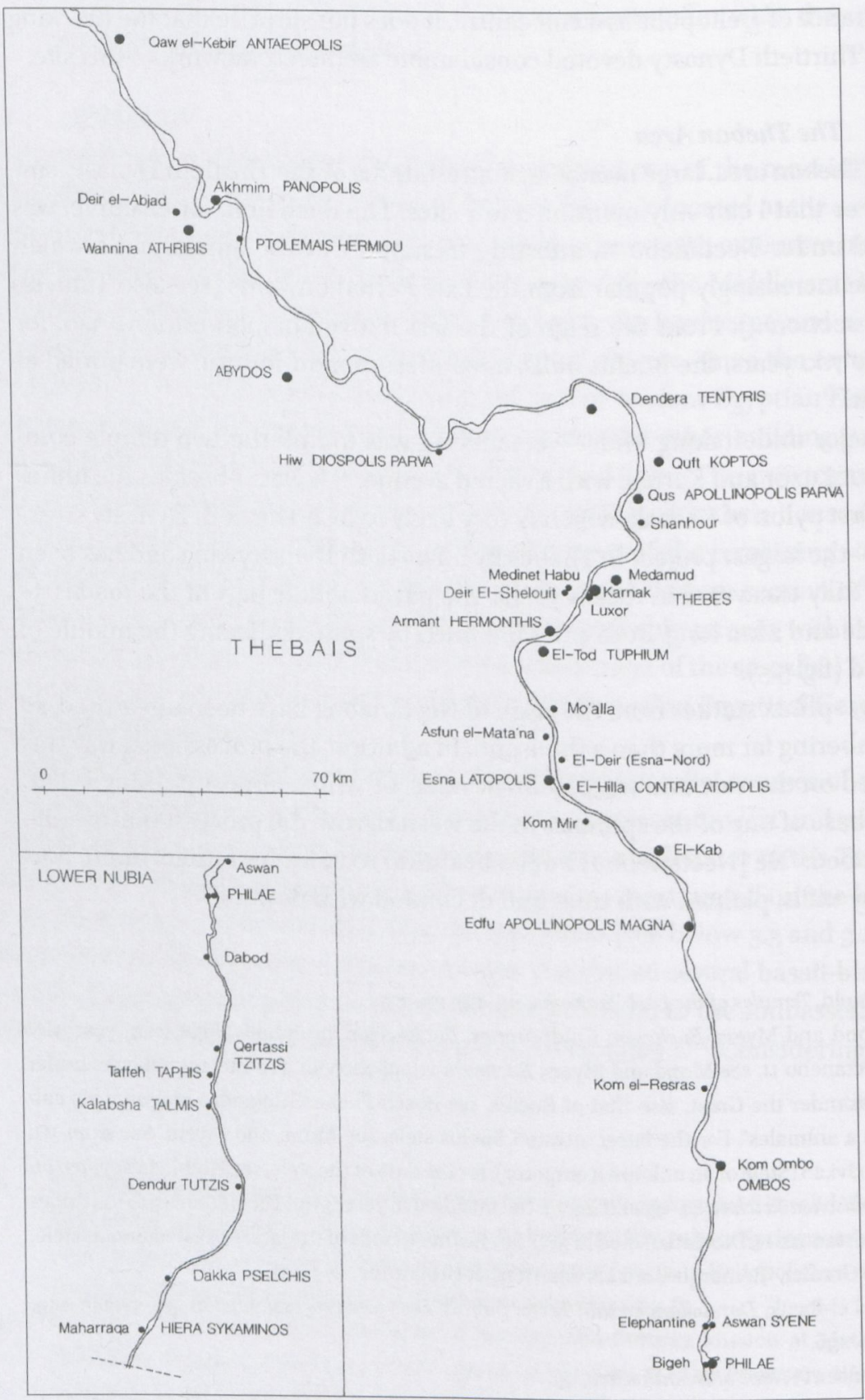

FIGURE 5.4 Map of upper Egypt

AFTER ARNOLD, TEMPLES OF THE LAST PHARAOHS, FIG. XVIII ON P. 22 


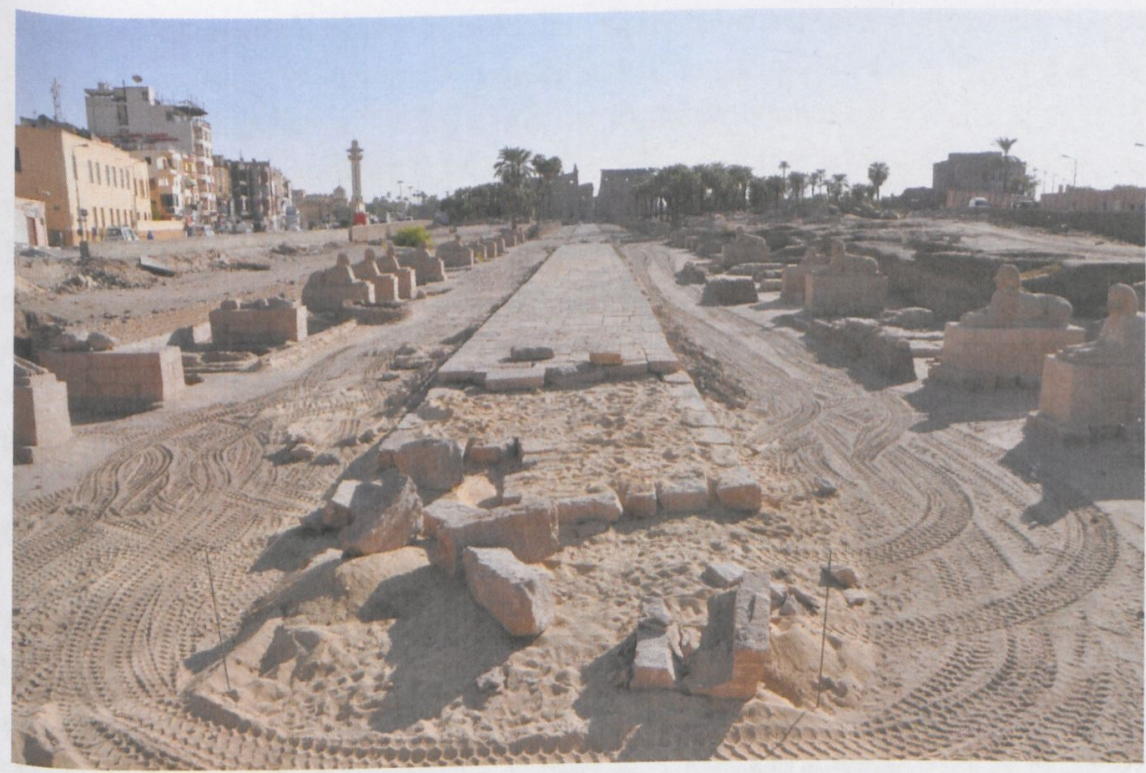

FIGURE 5.5 Sphinx avenue linking the temples of Luxor and Karnak

PHOTOGRAPH: TROY L. SAGRILLO

Other sacred avenues in the Theban area and in Egypt were embellished or renovated during the Thirtieth Dynasty. ${ }^{63}$ The avenue between Luxor and Thebes in particular provides an important glimpse of the interaction between sacred spaces and urban development. The brick walls physically separated sacred and profane areas. This separation was also emphasized by the huge, new brick enclosure wall around the complex of Amun at Karnak. ${ }^{64}$

\subsection{Elkab}

As is evident in Heliopolis and Karnak, another typical project of the Thirtieth Dynasty was to construct new enclosure walls that created significantly larger sacred areas. Spencer has identified these as the "most lasting legacy of the 3 oth Dynasty construction work". ${ }^{65}$ A good example is the enclosure wall at Elkab (fig. 5.6), the present-day name of the ancient Egyptian town of the vulture goddess Nekhbet, on the east bank of the Nile about $15 \mathrm{~km}$ north of Edfu, which had been inhabited since prehistory. Together with Wadjit of Lower Egypt, Nekhbet

63 Spencer, $A$ Naos of Nekhthorheb, 49.

64 Arnold, Temples of the Last Pharaohs, 115; Spencer, A Naos of Nekhthorheb, 49.

$6_{5}$ Spencer, A Naos of Nekhthorheb, 49. 


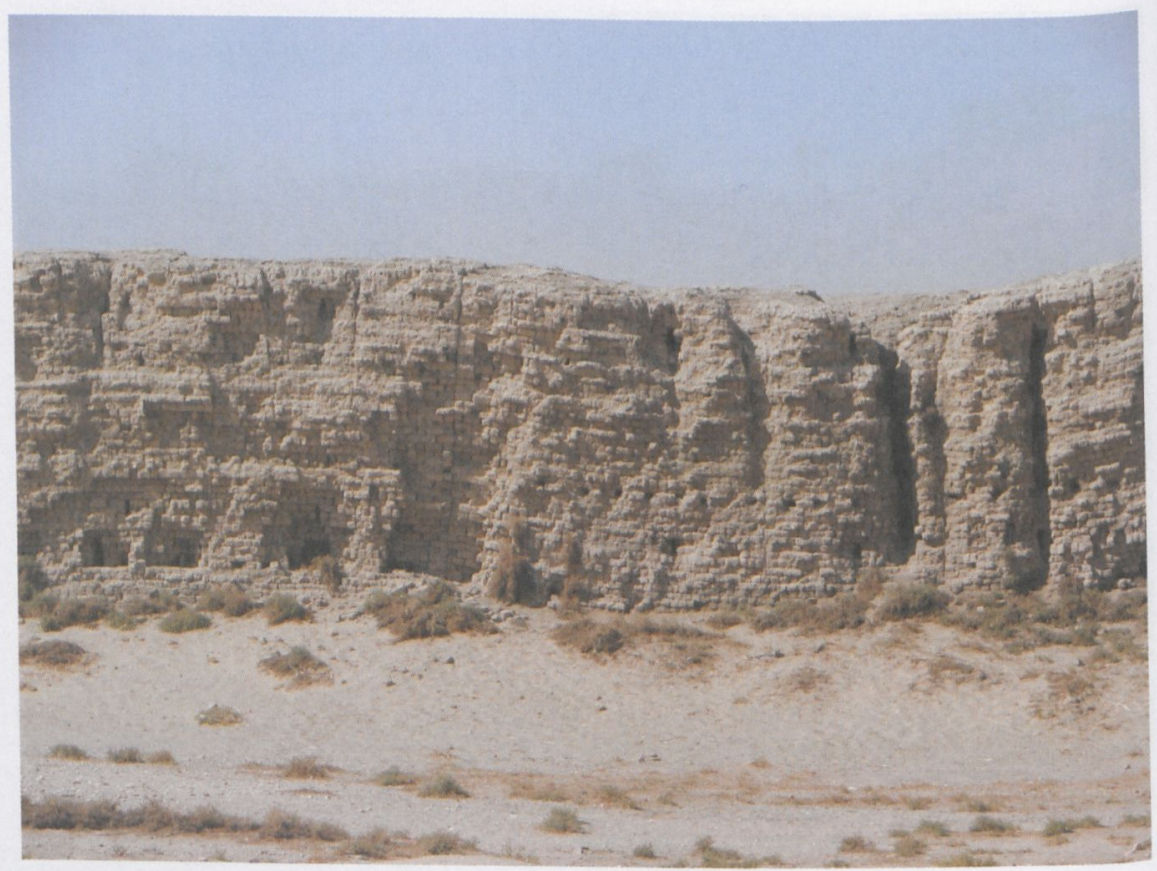

FIGURE 5.6 Elkab, enclosure wall

PHOTOGRAPH: AUTHOR

was the tutelary goddess of Egyptian kings and regarded as the Upper Egyptian goddess par excellence.

Elkab has a vast, almost square enclosure wall of $550 \times 550 \mathrm{~m}$. By surrounding the area with a massive brick wall, a significantly larger sacred space was created. The purpose of this enclosure cannot yet be identified clearly. It could have been a temple or even a town wall, since the temple complex within it was itself provided with two further brick enclosure walls. ${ }^{66}$ According to Spencer, the majority of temple enclosures should be interpreted as sacred structures, with no practical defence purpose intended at the time of construction. They should be seen as monumental reaffirmations of sacred space, extended beyond anything encountered before. ${ }^{67}$ This is yet another innovation of the Thirtieth Dynasty, later followed in the planning of Graeco-Roman

66 Depuydt, Archaeological-topographical Surveying of Elkab, map "Elkab". See also Rondot, "Une monographie bubastite", 270.

67 Spencer, A Naos of Nekhthorheb, 50. De Meulenaere, "Un général du Delta”, 209, suggested that the great enclosure wall was a defence structure ordered by Nectanebo II against further Persian invasions, which seems quite unlikely. 
temples. Numerous bark stations and small temples in the vicinity of the huge enclosure wall suggest intense processional activities, similar to those between Luxor and Karnak, as well as other places in the Theban area. ${ }^{68}$

Within the enclosure wall, adjacent to a New Kingdom temple to Sobek, a temple for Nekhbet had been built during the reigns of Darius I of the first Persian Period and Hakoris of the Twenty-ninth Dynasty, reusing blocks from structures of the New Kingdom and later ${ }^{69}$ Nectanebo I and II restored and embellished the temple. During the Thirtieth Dynasty, a birth house was also added, focusing on Nekhbet's character as a goddess who assisted at divine and royal births. ${ }^{70}$ Since Elkab was the sanctuary of the Upper Egyptian crown, this action exemplifies the desire to establish the legitimacy of the Thirtieth Dynasty.

Birth houses (also known as mammisis) like that at Elkab were added to late Egyptian temples as subsidiary buildings, dedicated to the divine child of a local triad. ${ }^{71}$ They were often erected in front of and facing the main temple, and scenes that relate to the birth and nurturing of the child god dominate their decoration. Since the divine child was identified with the king in a number of aspects, birth houses were probably also places devoted to the cult of the living ruler. The oldest surviving, securely identified birth house was built under Nectanebo I at Dendera. ${ }^{72}$ According to Arnold, there are slightly earlier examples dating to the Twenty-ninth Dynasty, ${ }^{73}$ for example the birth house of Harpara at the east side of the Amun-Ra-Montu temple at Karnak, which was begun in the reign of Nepherites I and enlarged under Hakoris and Nectanebo I. This finding supports Spencer's opinion that much of the cultural renaissance that is attested for the Thirtieth Dynasty may continue trends of the previous dynasty. ${ }^{74}$

68 Arnold, Temples of the Last Pharaohs, 134.

69 Limme, "Elkab", 468.

70 Arnold, Temples of the Last Pharaohs, 119, 133, pl. xII on p. 16; Spencer, A Naos of Nekhthorheb, 48 .

71 For an overview of the birth houses, see Arnold, Temples of the Last Pharaohs, 285-288; Kockelmann, "Birth house (Mammisi)".

72 Arnold, Temples of the Last Pharaohs, $115,285$.

73 Daumas, Les mammisis, 54; Arnold, Temples of the Last Pharaohs, 101-103, 288. There may also have been simple forerunners of this temple type dating to the Ramesside period, but they are lost (Arnold, Temples of the Last Pharaohs, 286). Birth houses are attested in texts of the end of the New Kingdom from Abydos and Thebes (de Meulenaere, "Isis et Mout du Mammisi"). 
It seems thus that the last native dynasties put emphasis on the legitimation derived from birth houses, and this was further pursued under the Ptolemies. Under Nectanebo I, these edifices were rather straightforward in design, more like a shrine with a forecourt and an access path. Under the Ptolemies, this temple type was enlarged and its architectural features further developed, so that the birth houses turned into proper temples, suitable for a daily cult ritual, ${ }^{75}$ gaining even more importance.

\subsection{Elephantine}

The island of Elephantine is situated in the Nile opposite the city of Aswan, ancient Syene, just north of the first cataract. At the south-east corner of the island, a very large new temple for the ram god Khnum, enclosed by a temple wall, was built under Nectanebo II, replacing a predecessor of the New Kingdom with Twenty-sixth Dynasty additions. ${ }^{76}$ Although the temple is ruined and its remains might appear rather modest today, much information about it has been extracted through careful excavation and recording. In 1960, Ricke published a first study, and in 1999 Niederberger produced a more detailed archaeological and architectural presentation. ${ }^{77}$

The situation on Elephantine island is quite unique. Under the last native pharaoh, the temple area was expanded to the north-west beyond the New Kingdom Khnum temple, where the temple of Yahweh, in 410 destroyed under Darius II, had been located. ${ }^{78}$ Because the temple was considerably larger than its predecessor, housing areas inhabited by ethnic Aramaeans at the rear of the temple were levelled. ${ }^{79}$ As Spencer points out in his review of Niederberger's study, it is rare that a stone temple reveals the plan and elements of wall decoration and architecture, with a clear visible relationship to the adjacent urban environment. ${ }^{80}$ This is particularly true of the Late Period, since

Daumas, Les mammisis, $86,96$.

$77 \quad$ Rickeld, Temples of the Last Pharaohs, 134

77 Ricke, Tempel Nektanebos' II, also included a short discussion of the Thirtieth Dynasty changes at the temple of Satet on Elephantine. Niederberger, Der Chnumtempel, 113-137, sets this structure in the wider context of temple buildings at the Late and Graeco-Roman periods. Jenni, Dekoration des Chnumtempels, 87-100, publishes the decoration of the Khnum temple, including a list of all architectural monuments dating to the reign of Nectanebo II. See Spencer, A Naos of Nekhthorheb, 47-52, for a discussion of temple building in Egypt in the Thirtieth Dynasty.

78 Niederberger, Der Chnumtempel, 13.

79 Spencer, Review of Niederberger, 274; 2006a, 48. See Niederberger, Der Chnumtempel, 108, Abb. 108, for the foundation of the temple.

8o Spencer, Review of Niederberger, 273. 
significant temples of the time are often overlaid by structures of the Ptolemaic and Roman periods. Elephantine is one of very few sites where temple and contemporary settlement have been excavated with modern expertise. In addition, the temple of Khnum is the only Thirtieth Dynasty temple whose ground plan can be more or less established from preserved foundations. It is also the only temple of this period for which an internal plan of rooms can be reconstructed.

Fragments of three Thirtieth Dynasty naoi were recovered within the temple. ${ }^{81}$ Like so many temples of the last native dynasty, the temple of Khnum was not finished before the second Persian period. The grand main portal, still standing today, was therefore decorated under Alexander IV, Alexander the Great's son (see section 4), and the temple was further extended under Ptolemaic and Roman rule, exemplifying the importance of the region in these periods; Syene was probably the important place and Elephantine the sacred area. ${ }^{82}$ According to Niederberger, the Iseum at Behbeit el-Hagar in the Delta (section 3.1.1 above) had a similar ground plan. Because of the similarities of the two temples, which are located at the opposite ends of Egypt, he postulates the same master plan for both temples. ${ }^{83}$ However, Elephantine was a provincial location; so was Behbeit el-Hagar, but still near Sais. We can assume that the master plans, if they existed, were devised in the cultural centre, which was in the north. The most creative regions must have been in the Delta, and huge temple complexes like Behbeit el-Hagar demonstrate this. In addition, we do not have enough evidence to be sure of what a typical Thirtieth Dynasty temple looked like. We only have Behbeit el-Hagar and Elephantine, but the plan for the Delta temple is very hypothetical. ${ }^{84}$ Therefore, caution is required in positing a typical temple plan of the Thirtieth Dynasty, since there are not sufficient surviving examples.

From the layout of the Khnum temple, we can extract two specific architectural features for the Thirtieth Dynasty. First, an ambulatory was introduced around the sanctuary, a feature that continued in the temples of the GraecoRoman period. Second, the open-air room associated with Re was transformed to a small solar or New Year's court, from which the wabet chapel or "pure hall", an elevated room, is reached by steps. Here, the cult image of the main deity

81 Niederberger, Der Chnumtempel, 86-91.

82 Minas, "Die Dekorationstätigkeit", Teil 2, 100-102; Coppens, Wabet, 19; Arnold, Temples of the Last Pharaohs, 134. Under Augustus, further extensions were added, including a monumental platform (Hölbl, Altägypten im Römischen Reich II, 29-33).

83 Niederberger, Der Chnumtempel, 118.

84 Spencer, Review of Niederberger, 276-277. See also Yoyotte, Histoire, géographie et religion de l'Égypte ancienne, esp. chapters 34 and 46. 
of the temple was set down and clothed. In the court, some of the New Year's offering took place before the priests carried the cult image up to the roof via the staircases. Predecessors of the wabet and the New Year's court are found in the solar courts of New Kingdom cult temples. The wabet as reconstructed for the Khnum temple represents the earliest known example that had an adjoining court. ${ }^{85}$

The main cult axis developed already in the later New Kingdom, but it is characteristic of the temples from the Thirtieth Dynasty onwards. ${ }^{86}$ The last native ruler thus not only continued traditions, but also developed something new, a standardized conception of temple building, on which those of the Graeco-Roman period were based. ${ }^{87}$

In this context, composite capitals should be mentioned, since these too are distinctive features of temples constructed or extended from the Thirtieth Dynasty until the Roman period. ${ }^{88}$ Traditionally, the capitals of columns in any one row were uniform, but, from the Thirtieth Dynasty onwards, different capital types were combined according to rules of axial correspondence. ${ }^{89}$ In 2009, Fauerbach devoted a study to the creation of composite capitals in the Ptolemaic period: floral capitals were not based on grids, but on complex drawings that were divided to show both plan and elevation. She describes the five steps for creating such capitals, ${ }^{90}$ and she is able to prove from drawings on the pylon of Edfu temple that the Egyptians of the second century BCE were familiar with the use of scale drawings.

\subsection{Philae}

Philae, an island in the Nile at the south end of the first Nile cataract, was sacred to Isis. In the 1970s, the architectural structures of the original island were moved to their present location on the island of Agilkia when Philae was becoming permanently flooded by the construction of the Aswan High Dam. ${ }^{91}$

85 According to Coppens, Wabet, 221, the complex of wabet and court is situated at the end of a development that started at least a millennium earlier. The New Kingdom solar courts seem to be the simpler forerunners of this structure.

86 Niederberger, Der Chnumtempel, 113-114, 121.

87 Assmann, "Der Tempel der ägyptischen Spätzeit", 10-n (and Moses the Egyptian, 179), states that the late Egyptian temples follow in fact a "einheitlichen Baugedanken, d.h. einem kanonischen Plan" much more closely than the temples of the earlier periods.

88 Phillips, Columns of Egypt, 161.

89 For example, Arnold, Temples of the Last Pharaohs, 149; McKenzie, Architecture of Alexandria and Egypt, 122-132.

90 Fauerbach, "Creation of an Egyptian Capital", 11.

91 Winter, "Philae", 1022-1028. Locher, Topographie und Geschichte, 121-158, provides a summary of the topography and history of Philae and a useful bibliography. 
The temple of Isis and its associated structures are the dominant monuments on the island. Philae's history before the Thirtieth Dynasty is hardly known; ${ }^{92}$ the extant structures are mainly Graeco-Roman and belong to the policy of promoting Isis. ${ }^{93}$

Under Nectanebo I, a project was developed to enlarge the sanctuary of Isis at Philae, whose cult seemed to have gained importance in all of Egypt, as is also shown by the Iseum of Behbeit el-Hagar in the Delta (see above section 3.1.1). A gate had been erected, which is now placed in the first pylon of the temple of Isis, initiated under Ptolemy II Philadelphos and replacing an earlier temple. ${ }^{94}$ Originally, the gateway was set in a brick enclosure wall; it is not connected with the pylon's two towers, which were probably built under Ptolemy vi Philometor. ${ }^{95}$ The precise extent of the sacred enclosure under Nectanebo I remains unknown, since later buildings obliterated all earlier traces. In contrast to the temple of Isis at Behbeit el-Hagar, where the existing temple of the Thirtieth Dynasty was expanded and decorated under Ptolemy II and Ptolemy III, the temple of Isis at Philae built under Ptolemy II was a new and integrally planned architectural unit.

The main building of the Thirtieth Dynasty at Philae is a $7.6 \times 11.5 \mathrm{~m}$ kiosk, now located at the south end of the island, which originally stood at a different place. It stands on a platform and consists of a rectangle of four by six columns. Their capitals display a combination of Hathor and composite floral capitals (fig. 5.7).

The kiosk seems to have been moved in the mid-second century BCE and turned 180 degrees, as has been established from details of its decoration. ${ }^{96}$ Shape and location seem to suggest that the building served in its new posi-

92 Blocks of Taharqa of the Twenty-fifth Dynasty have been found, but a kiosk built under Psammetik II of the Twenty-sixth Dynasty is the oldest building that certainly belongs to Philae (Haeny, "Architectural History of Philae", 201-202).

93 For the hymns to Isis in her temple at Philae, see Žabkar, Hymns to Isis. See also Fissolo, "Isis de Philae". Arsinoe II shared as a synnaos thea the temple with Isis and participated in her veneration. As a living and deceased queen, Arsinoe II provided a vital image for the Ptolemaic dynasty, offering legitimacy for herself, her brother-husband Ptolemy II, and their successors through iconographic and textual media. She was given epithets that were used not only for later Ptolemaic queens, but also for Isis. Arsinoe's connection with Isis might well have contributed to the decision to enlarge the temple at Philae considerably under Ptolemy II. For an analysis see Minas-Nerpel, "Ptolemaic Queens as Ritualists and Recipients of Cults: The Cases of Arsinoe II and Berenike II" (esp. section 2). Winter, "Philae", 1022 (J); Vassilika, Ptolemaic Philae, 25-27.

95 Minas, "Die Dekorationstätigkeit", Teil 2, 102-103.

96 Winter, "Philae", 1022 (A); Haeny, “Architectural History of Philae", 204-206, 224. 


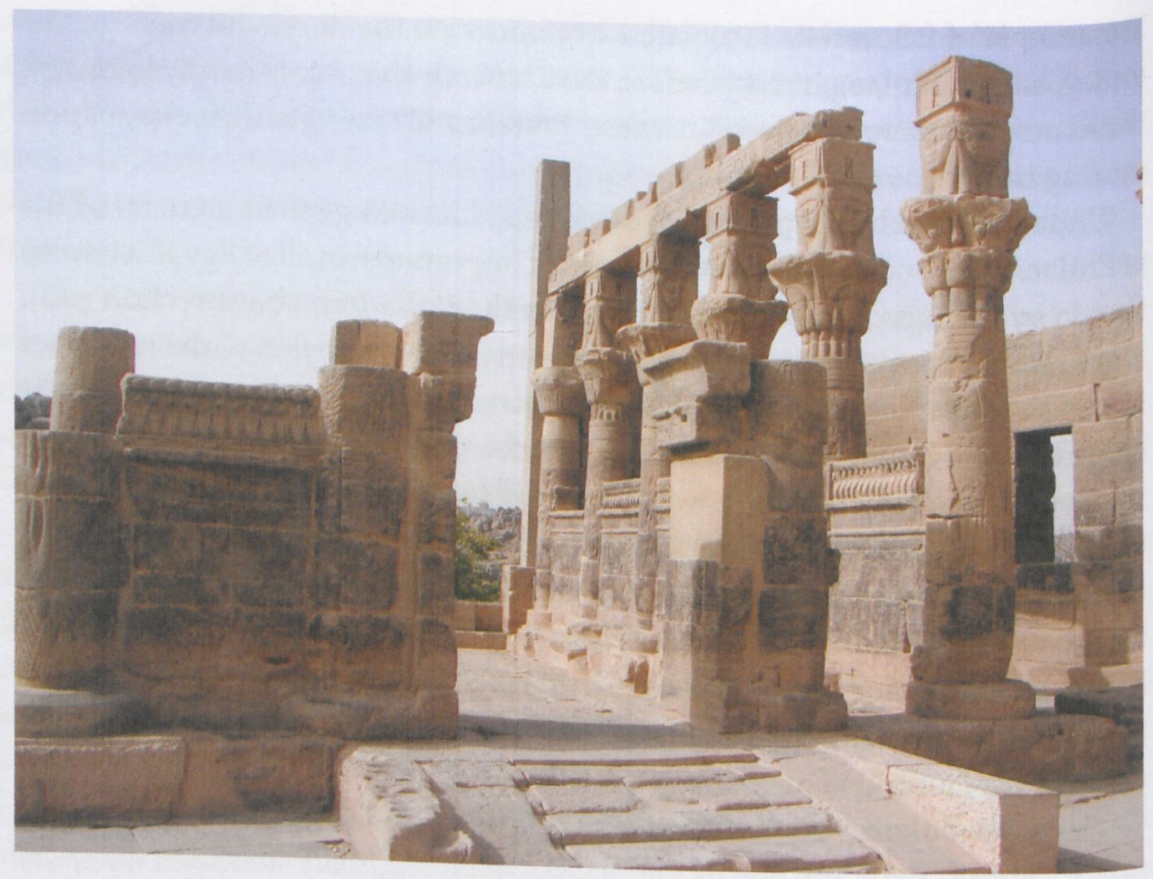

FIGURE 5.7 Philae, kiosk of Nectanebo I

PHOTOGRAPH: AUTHOR

tion as a way station, but, according to Arnold, it previously could have been the ambulatory of a birth house. ${ }^{97}$ This interpretation seems unlikely, though, since such a structure would have been very small.

Niederberger connects the construction programmes of Elephantine and Philae and concludes that both the Nectanebos had to concentrate on one of the two sites at the expense of the other, for kings like them, residing in the Delta would not have had the means to conduct two large projects. ${ }^{98}$ This is, in his eyes, the reason why the Khnum temple could not have been planned under Nectanebo I. Indeed, his cartouches are not preserved, but this idea is rather perplexing, as Spencer also points out, since evidence from elsewhere in Egypt suggests that temples were built at sites near to one another under the Thirtieth Dynasty. ${ }^{99}$

97 Arnold, Temples of the Last Pharaohs, 119.

98 Niederberger, Der Chnumtempel, 14.

99 Spencer, Review of Niederberger, 276. In addition, Nectanebo I erected a gate on Elephantine that was an extension to the New Kingdom structure (Arnold, Temples of the Last Pharaohs, 119). 

Soter

No traces of temple building during the second Persian period are currently known, and this is not surprising, since in times of such turmoil no temple wall was decorated. This situation changed under Alexander the Great, who realized the importance of maintaining the integration of "church and state". With his alleged coronation as pharaoh at Memphis ${ }^{100}$ and subsequent consultation of the oracle in Siwa Oasis in the Western Desert, where he was declared the son of Zeus-Ammon, Alexander demonstrated that he was willing to act as pharaoh and be legitimized by Egyptian gods - useful for someone who was about to conquer the world. A legitimate pharaoh had to care for Egypt by fighting against its enemies and by providing temples and cults for the gods, and he fulfilled these tasks, which benefited those whose service he required, that is, the Egyptian elite.

In addition, a legendary link to Nectanebo II was established: in the Alexander Romance, a popular novel of the Hellenistic world, Alexander the Great is connected with his "real" father, the last native pharaoh of Egypt. Nectanebo II is described as a powerful magician who caused Olympias, Alexander's mother, to believe that she had been impregnated by the Egyptian god Amun. ${ }^{101} \mathrm{~A}$ further narrative, "Nectanebo's Dream", was most probably also translated into Greek from an Egyptian original. This prophecy, concerning the demise of Egypt's last native pharaoh, was used as nationalistic propaganda against the Persian rulers who conquered Egypt, so that it can be assumed that the author came from the Egyptian elite or priesthood. Its sequel, as Ryholt states, was used in favour of Alexander the Great, which underlines the sophisticated use of political propaganda. ${ }^{102}$

100 Winter, "Alexander der Große als Pharao", 205-207, provides an overview of the evidence. Contra Burstein, "Pharaoh Alexander", who does not believe that Alexander was crowned in Egypt. See also Pfeiffer "Alexander der Große in Ägypten”. For a discussion of Alexander as pharaoh and the attestations of his royal titulary see Bosch-Puche, "Egyptian Royal Titulary" I and II (hieroglyphic sources); Bosch-Puche and Moje, "Alexander the Great's Name" (contemporary demotic sources).

101 For the context of the Graeco-Egyptian Alexander Romance and its Egyptian origins of Alexander's birth legend, see Hoffmann, "Der Trug des Nektanebos", 165-166, 348-349. For a translation and analysis of the Greek version, see Dowden, "Pseudo-Callisthenes", and Jasnow, "Greek Alexander Romance”. Ryholt, “Nectanebo's Dream”. For the Greek version of Nectanebo's Dream, see Gauger, 
Alexander was perceived and promoted as the liberator from the Persians. In his reign, Egyptian temples in the Delta, Hermopolis Magna, the Theban area, and Baharia Oasis were extended and embellished. ${ }^{103}$ Particularly significant is the bark sanctuary, built within the Luxor temple, dedicated to the state god Amun. ${ }^{104}$ Luxor temple was of utmost importance for the ideology of kingship. During the Opet festival at Luxor, the king was worshiped as the living royal $\mathrm{ka}$, the chief earthly manifestation of the creator god. As a god's son, Alexander was himself a god. His "visible activities in the human world had invisible counterparts in the divine world, and his ritual actions had important consequences for the two parallel, interconnected realms". ${ }^{105}$ It is very significant that Alexander decided, no doubt on advice from the priests, to rebuild a bark shrine in precisely this temple. He was thus connected with the great native rulers of Egypt and their ka by renovating the divine temple of Luxor. ${ }^{106}$ The ancestral ka of the Eighteenth and Nineteenth Dynasty kings was reborn in Alexander, and he was associated once more with Amun, first in his Libyan form of Ammon in Siwa, now with Amun-Re, the all-powerful Creator and king of gods.

Under Alexander's direct successors, his brother Philip Arrhidaios (323-317) and his son Alexander IV (317-310), Egyptian temples continued to be decorated. ${ }^{107}$ Work accomplished under them includes the decoration of the bark sanctuary of Philip Arrhidaios in Karnak, perhaps already constructed under

“Traum des Nektanebos”. See also Hoffmann, “Der Trug des Nektanebos”, 162-165, 348. See above, section 3.1.1 above (with notes 20-21).

103 For a list of attestations of Alexander's building activity at Egyptian temples, see Arnold, Temples of the Last Pharaohs, 138; Winter, "Alexander der Große als Pharao"; Blöbaum, "Denn ich bin ein König ...", 361; Chauveau, "L'Égypte en transition", 390-393; Schäfer, "Alexander der Große. Pharao und Priester"; Bosch-Puche, "Egyptian Royal Titulary of Alexander the Great" I and II. Ladynin, "The Argeadai building program in Egypt".

104 Abd el-Razik, Darstellungen und Texte; Waitkus, Untersuchungen zu Kult, vol. I, 45-6o, vol. II, 6o-89.

105 Bell, "New Kingdom (Divine) Temple", 180.

106 Bell, "Luxor Temple", and Bell, "New Kingdom 〈Divine〉 Temple”. Contra: Waitkus, Untersuchungen zu Kult, 280-281, who assumes that the ka does not play an overly important role in the temple of Luxor.

107 For a list of attestations, see Blöbaum, “Denn ich bin ein König ...", 362 (Philip Arrhidaios), 362-363 (Alexander IV); Chauveau, "L'Égypte en transition”, 393-395 (Philip Arrhidaios), 395-396 (Alexander IV); Ladynin, "The Argeadai building program in Egypt", 223-228 (Alexander iII to Alexander IV). 
Nectanebo II, ${ }^{108}$ and of a gate at the temple of Khnum on Elephantine, ${ }^{109}$ which was inscribed with the names of Alexander IV (fig. 5.8).

The amount of building work undertaken in the relatively short Macedonian period is in no way comparable with that of the thirty-seven years of the Thirtieth Dynasty, either in the amount or in inventiveness. Alexander the Great used the ideas of Egyptian divine kingship for his own purpose and thus fulfilled the requirements. Under his two immediate successors, Egyptian kingship cannot have played the same major role, but the native priests had at least enough funds to continue with the building work, although Philip Arrhidaios and Alexander IV, a relatively small child, never visited Egypt. Ptolemy the Satrap, who ruled the country in their name as an absolute autocrat, must have had input into the decisions. The Satrap Stele shows that by 311 he was in charge. One can also imagine the Ptolemies, as believers in religion in general, would have accepted the local gods and assumed they should support them. During his reign as Ptolemy I (306-283/2), much emphasis was put on religious politics, as the creation, or at least active promotion, of the cult of the Graeco-Egyptian god Serapis attests. From Ptolemy II onwards, that cult was closely connected with the ruler-cult.110

When they assumed power, the Ptolemies had to establish a stable political base. It was therefore necessary to respond to the needs of the Egyptian population, to which the native priesthoods held the key. On the Satrap Stele it is reported that Ptolemy the Satrap attended to the needs of the Egyptian temples already when governor. ${ }^{111}$ The stele was once set up in a temple, according to its texts presumably in Buto in the Delta, but was discovered in 1870 in Cairo, re-built in a mosque. It is now housed in the Egyptian Museum (CGC 22182). Its date in line 1, the first month of Akhet, year 7 of Alexander IV (November/December 311) is also the terminus ante quem for the move of the capital to Alexandria, described in line 4: "Ptolemy moved his residence to the enclosure of Alexander on the shore of the great sea of the Greeks (Alexandria)".

108 Barguet, Le temple d'Amon-Rê, 136-141. For further references, see Arnold, Temples of the Last Pharaohs, 140; Chauveau, "L'Égypte en transition", 394; Blöbaum, "Denn ich bin ein König ...”, 362, no. Ar-PA-o1o.

109 Bickel, "Dekoration des Tempeltores". According to Arnold, Temples of the Last Pharaohs, 141, several relief blocks at Sebennytos in the Delta (see fig. 5.1) with the name of Alexander IV confirm that the decoration of the granite walls of the temple of Nectanebo II for Osiris-Shu, suspended in 343 when the Persians re-conquered Egypt, was resumed. See also section 3.1 above.

110 Pfeiffer, "The God Serapis".

For references to the Satrap Stele, see Section 2 above, including n. 16. 


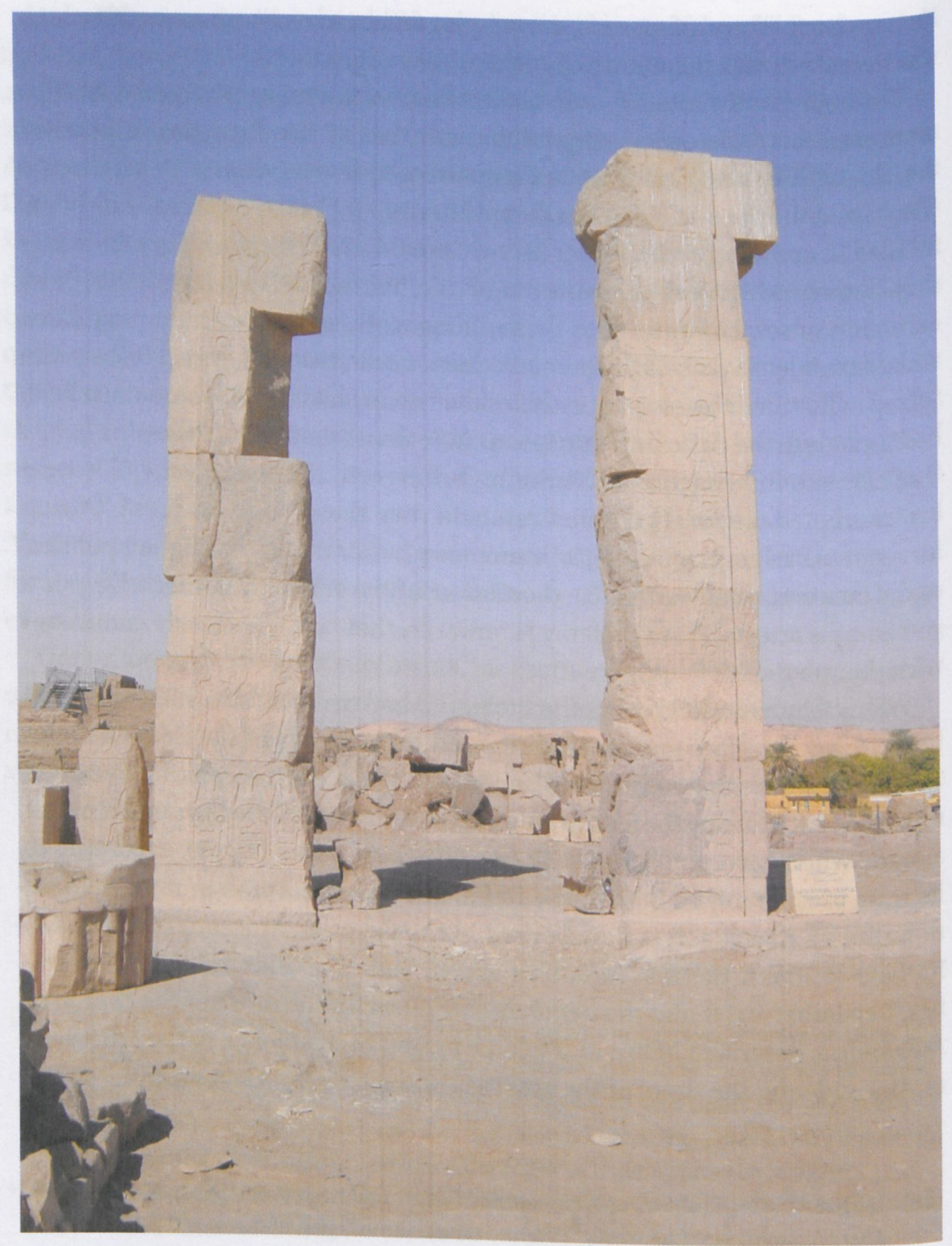

FIGURE 5.8 Elephantine, temple of Khnum, gate of Alexander IV PHOTOGRAPH: AUTHOR

For the present discussion, the last section of the Satrap Stele (lines 12-18), in which the earlier donation of Khababash, probably a native rival king during the Persian occupation, is of particular importance: Ptolemy reaffirms the priests in their possession of certain areas of the Delta in order to support the 
temple of Buto. In return, the priests reassure him of divine support, which, of course, implies their own support. This example is a key to understanding the effort which went into constructing temples and thus caring for the Egyptian cults: according to the principle do ut des, the Ptolemaic ruler would be blessed and supported by the Egyptian deities and thus by the clergy.

Alexander the Great's benevolent attitude to the Egyptian temples and cults must have served as a crucial model for Ptolemy I Soter and his successors. The latter not only developed huge new projects, but also continued with largescale temple building and decoration, where Thirtieth Dynasty projects had been interrupted by the second Persian occupation. Since Soter's reign was overshadowed by wars against the other Diadochoi and much of the country's resources was spent on developing Alexandria and on founding Ptolemais Hermiou in Upper Egypt, it is not surprising that his building projects did not equal those of the Thirtieth Dynasty or the later Ptolemaic rulers, especially Ptolemies vi Philometor and vin Euergetes II. ${ }^{112}$ However, his name appears on several chapels, temple reliefs, and stelae. Swinnen published in 1973 a study of the religious politics of Ptolemy I Soter, including a list of places where Egyptian temples were extended or embellished during his rule. At the following places, from north to south, Soter's names are preserved:113 Tanis; perhaps Behbeit el-Hagar; ${ }^{114}$ Terenouthis at the western edge of the Delta, where a temple for Hathor-Therenouthis was begun; Naukratis, ${ }^{115}$ where a presumably unfinished Egyptian temple of the Thirtieth Dynasty was located; Tebtynis, where a new temple for the local crocodile god Soknebtunis was built; blocks are attested from Per-khefet, probably near Oxyrhynchos; Sharuna, where a temple was begun under Ptolemy I and decorated under Ptolemy II; Cusae (el-Quseia), where a Hathor temple was built; Tuna el-Gebel; Hermopolis; possibly Edfu; ${ }^{116}$ and Elephantine.

112 Minas, "Die Dekorationstätigkeit", Teil 1 and Teil 2.

113 Swinnen, "Sur la politique religieuse de Ptolémée Ier", 118. Further refined by Arnold, Temples of the Last Pharaohs, 154-157. See also Derchain, Zwei Kapellen, 4, n. 10-11, who referred to possible building activities in Akhmim and Medamud, but the evidence is unclear.

114 See n. 27 above: Swinnen, "Sur la politique religieuse de Ptolémée Ier", 118, cautiously connected a naos found at Mit Ghamr, inscribed with Soter's cartouches, with Behbeit el-Hagar. Arnold, Temples of the Last Pharaohs, 154-157, does not list the site.

115 See also Yoyotte, Histoire, géographie et religion de l'Égypte ancienne, 309 (with further references).

116 In 1984, at least thirty-nine decorated and undecorated blocks from earlier structures were excavated under the pavement of the Ptolemaic forecourt of the Edfu temple. Many fragments can be assigned to a Kushite Sed-festival gate. Others bear inscriptions of a Seventeenth Dynasty king, Thutmose III (Eighteenth Dynasty), Saite kings (Twenty-sixth 
Most traces of Soter's building programme come from Middle Egypt, especially from Sharuna and Tuna el-Gebel. Hermopolis and its necropolis Tuna el-Gebel were vibrant cult places at the time of transition from the Thirtieth Dynasty to the early Hellenistic period, and Soter's building activity in this area demonstrates that the Ptolemies often built at places favoured by the Thirtieth Dynasty. Khemenu, Greek Hermopolis, was the capital of the Fifteenth Upper Egyptian nome and had been an important administrative centre since an early date. The inhabitants of Hermopolis apparently assisted Nectanebo I, then only a general, against Nepherites II, the last king of the Twenty-ninth Dynasty, and Nectanebo I therefore embellished the site with massive temple buildings that are mostly lost, but described in the text of a limestone stele, now in the Egyptian Museum Cairo (JE 72130). The stele is $2.26 \mathrm{~m}$ high and inscribed with thirty-five lines of hieroglyphic text. ${ }^{117}$ Also under Nectanebo 1, the temple of Nehemet-away was constructed and the temple of Thoth renovated. Nehemetaway was a creator goddess and consort of Thoth; according to the stele, both deities were responsible for Nectanebo's ascent to the throne (section c, 1. 911). ${ }^{118}$ The inscription not only gives technical details of the temple construction and decoration, but also attests to the use of royal propaganda, including the divine selection of the king by a god and goddess, as well as rewards to the local priesthood for their support in gaining the throne. The temple of Thoth was further expanded under Nectanebo II and Philip Arrhidaios. ${ }^{119}$

Tuna el-Gebel and Hermopolis continued to play an important role into the Roman period. Monuments include a wide variety of funerary chapels in the form of small temples at the necropolis of Tuna el-Gebel, of which that of Petosiris, high priest of Thoth, is the best preserved and highly innovative, constructed around $300 \mathrm{BCE} .{ }^{120}$

Dynasty), and the throne name stp-n-remrj-jmn. This throne name could belong to Alexander the Great, Philip Arrhidaios, or Ptolemy I Soter, indicating that the current temple is based on foundations that include Macedonian or early Ptolemaic blocks. See Leclant and Clerc, "Fouilles et travaux 1984-85", 287-288; 1987, 349, fig. 56-59 on pls. 43-45; Arnold, Temples of the Last Pharaohs, 50; von Falck, "Geschichte des Horus-Tempels" (with further references, but not to the Macedonian-Ptolemaic throne name or structure); Patanè, Marginalia, 33-36 (colour plates). I thank John Baines and Erich Winter for sharing their photographs of this throne name with me.

117 Roeder, "Zwei hieroglyphische Inschriften", 375-442. See also Grallert, Bauen - StiftenWeihen, 503-504, 672; Klotz, "Two Overlooked Oracles".

118 Roeder, "Zwei hieroglyphische Inschriften", 390-391.

119 Arnold, Temples of the Last Pharaohs, 111, 131. See Kessler, "Hermopolis", 96.

120 Lefebvre, Tombeau de Petosiris; Cherpion et al., Le tombeau de Pétosiris à Touna el-Gebel. For an overview and the context, see Lembke, "Petosiris-Necropolis", 231-232. 
Tuna el-Gebel is also famous for its animal cemeteries and the burial of mummified ibises, the sacred animals of Thoth. The practice begun in the Twenty-sixth Dynasty, and the cult received increasing attention under the Thirtieth Dynasty, whose reforms of animal cults were continued under the Ptolemies. ${ }^{121}$ Several underground chapels, cased with limestone blocks, were connected to the subterranean Ibiotapheion. These, which belong to the time of Ptolemy I, are decorated in partly well preserved colours, on which the grid system still survives in some cases. In comparison to the rest of Soter's construction work, two relatively well preserved cult chapels for Thoth in his form of Osiris-Ibis and Osiris-Baboon from Tuna el-Gebel, now housed in the Roemerand Pelizaeus-Museum Hildesheim (fig. 5.9) and in the Egyptian Museum Cairo.

They exemplify strong royal support for the animal cult at the beginning of the Ptolemaic period, at a site where reliefs in Hellenizing style are attested for the first time in Petosiris' tomb chapel. ${ }^{122}$ The surviving reliefs in the chapel show the king offering to Thoth in several manifestations, Isis, Harsiese, and further deities. ${ }^{123}$ Kessler assumes that these chapels were part of a larger construction project that probably also included the above-ground wabet and the great temple of Thoth. When exactly in the reign of Ptolemy I Soter the project was begun remains unclear. Kessler suggests 300-295, but the planning might have started as early as the reign of Philip Arrhidaios, when Ptolemy was already ruling Egypt as satrap and involved in the cult politics. ${ }^{124}$

None of Soter's temples survives. Only blocks or traces of buildings are preserved, most of them coming from Middle Egypt. This pattern distorts the picture of the construction and decoration work under Ptolemy I. ${ }^{125}$ The sociocultural context of the Egyptian temples in the Ptolemaic period, their function as centres of learning that produced vast numbers of hieroglyphic and literary texts, and their artistic aspects are almost exclusively known through later

121 Kessler, Die heiligen Tiere, 194-219, 223-244.

122 For Petosiris' input into the building and decoration programme, see Kessler, Tuna el-Gebel II, 126-131.

123 Derchain, Zwei Kapellen; Karig, "Einige Bemerkungen”; Kessler, Tuna el-Gebel II, 2, demonstrates that the reliefs published byDerchain belong to the "Paviankultkammer G-C-C-2" in Tuna el-Gebel and adjusts Derchain's sequence of scenes.

124 Kessler, Tuna el-Gebel II, 130. The cartouches of Alexander's brother Philip Arrhidaios are attested inside the great temple of Hermopolis.

125 Derchain, Zwei Kapellen, 4-5, assumed that the centre of Soter's construction work was in Middle Egypt since most finds come from there (see map on his p. 5). 


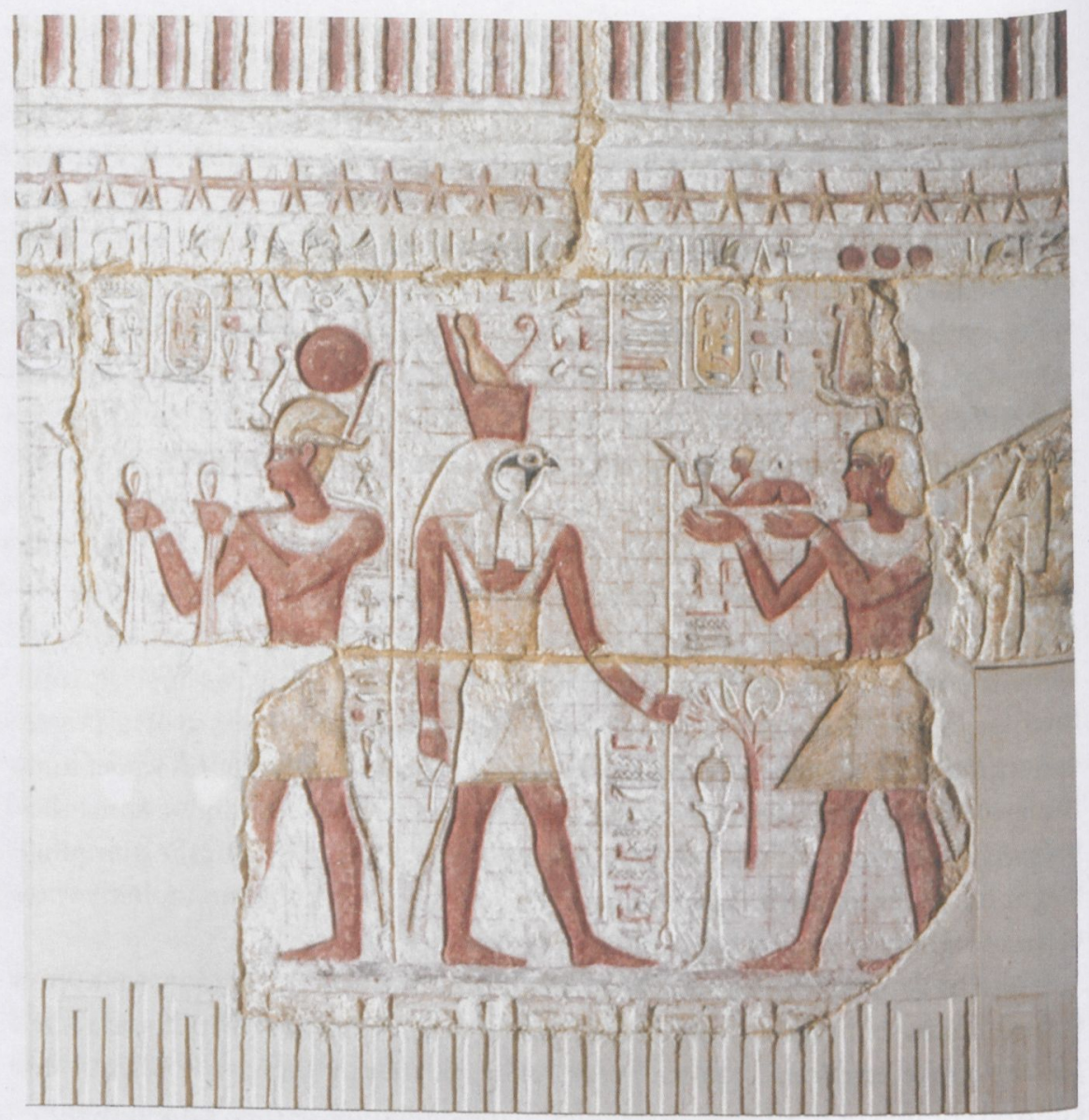

FIGURE 5.9 Tuna el-Gebel, chapel of Ptolemy I Soter, now in Roemer-and Pelizaeus-Museum PHOTOGRAPH: ROEMER- AND PELIZAEUS-MUSEUM HILDESHEIM

examples, almost completely in southern Upper Egypt. ${ }^{126}$ The cultural centre, however, was in the north and the most creative regions were probably in the Delta and the Memphite area. Therefore, one could assume that temples in the north were larger and more richly decorated than those in the provincial south. The bias towards the south causes well-known problems of interpretation.

According to a mythical text in the temple of Horus at Edfu, monumental temple architecture was developed north of Memphis near the sanctuary of Imhotep close to Djoser's pyramid, dating to the Third Dynasty. ${ }^{127}$ The current

126 Finnestad, "Temples of the Ptolemaic and Roman Periods", 198, 227-232.

127 Wildung, Imhotep und Amenhotep, 146, paragraph 98. 
Ptolemaic temple at Edfu replaced a much older construction that seems to have had a link to Memphis. ${ }^{128}$ The enclosure wall is said to be a similar construction to that first begun by those of old, "like what was on the great ground plan in this book which fell from heaven north of Memphis" ( $m j$ wn hr snt wr $n$ md $3 . t$ tn h3j.t $n$ p.t mh.t jnb had $).{ }^{129}$ Another text in the same temple states that the pattern which the Ptolemaic builders followed when constructing this enclosure wall was derived from "the book of designing a temple" ( $̌$ fd.t $n$ sšm hw.t-ntr r), which Imhotep himself was supposed to have composed. ${ }^{130}$

We also learn from the Edfu text that temple architecture was canonical, which means that the temple can be understood as the three-dimensional realization of what was written in "the book". One might wonder whether this inscription refers to the "Book of the Temple", ${ }^{131}$ a handbook or manual that, as Quack establishes, describes how the ideal Egyptian temple should be built and operated. This book is attested in over forty fragmentary manuscripts, demonstrating its wide and supra-regional distribution in antiquity. The mostly unpublished papyri all date to the Roman period, but the manual's origin predates the foundation of Edfu in $237 \mathrm{BCE}$.

\section{Conclusion}

As Spencer emphasizes, the temple complexes of the Late Period, especially those of the Thirtieth Dynasty, should be seen as "emblems of Egyptian culture". ${ }^{132}$ With the enclosure walls, encircling layers of dark rooms, halls, and corridors, the sanctuaries in the temples of the last native dynasty were much more protected than earlier ones, thus enhancing the feeling of seclusion. And in the most sacred area of these fortress-like temples were placed the naoi. The divine world was shielded from the human world, creating a protected dwelling space of the divine, with its protection emphasized by the darkness of the entire temple structure, especially the sanctuary. The only light filled structures were the pronaoi, colonnaded courts, and the rooftop with its kiosk, necessary

\footnotetext{
128 See n. 116 above for comments on archaeologically attested earlier structures.

129 Edfou vi 6, 4. Translation by author. See Blackman and Fairman, "Myth of Horus at Edfu", 36.

130 Edfou vi 10, 10. Translation by author. See Blackman and Fairman, "Myth of Horus at Edfu", 36.

131 Quack, "Die Theologisierung der bürokratischen Norm".

132 Spencer, $A$ Naos of Nekhthorheb, 51.
} 
for the New Year festival and for greeting the rising sun. Assmann states that this defensive character might reflect political circumstances, especially after the Persian occupation, ${ }^{133}$ but this might be a retrospective construction based on our knowledge of how Egyptian civilisation came to an end; before the first century, or even a bit later, temple construction could have felt like a golden age. On the other hand and on a more practical level, the fourth century was a time of fortification building, ${ }^{134}$ and the temple enclosure walls seem to have been used by Ptolemaic garrisons, with the Ptolemaic kings reinforcing the link between the army and the temples. ${ }^{135}$

A general increase in decoration within temples can be discerned from the Old Kingdom onwards, culminating in the large Graeco-Roman period temples. The temple walls were decorated on an unprecedented scale with scenes and inscriptions that provide manifold insights into the religious thinking of the priests, cult topography, mythology, religious festivals, daily cults, the ruler cult, and building history, as well as the functions of various rooms. The texts display the codification of knowledge on an unprecedented scale. The periods of foreign rule over Egypt seemed to have reduced the self-evident implications of temples and made it necessary to transcribe priestly knowledge on the temple walls, exceeding what was necessary for ritual purposes. This development was accompanied by the evolution of the writing system: the Egyptian scholar priests of the Graeco-Roman period developed for the indigenous temples a highly intellectual, very artificial language and a vastly expanded hieroglyphic writing system.

A very distinctive feature that exemplifies the new degree of codification and organization is the framing column in ritual offering scenes: Graeco-Roman period temples exhibit a highly meaningful organisation of these, and they were distributed in registers over entire walls. The so-called Randzeile, or framing column of the Graeco-Roman period temple reliefs, started to develop into its distinctive formula already in the Thirtieth Dynasty, as Winter established. ${ }^{136}$ According to Baines, who studied New Kingdom forerunners, there remains a salient distinction between the designs of the New Kingdom and the

133 Assmann, Das kulturelle Gedächtnis, 179: “Die Architektur ist geprägt durch Sicherheitsvorkehrungen, die von einem tiefen Gefährdungsbewußtsein, einer Art "Profanisierungsangst" diktiert sind."

134 See, for example, the fortification of Pelusium: Diodorus Siculus, Bibliotheca historica, XV 42, 13. See Carrez-Maratray, Péluse et l'angle oriental du delta Egyptien, 93: no. 149.

135 See Dietze, "Temples and Soldiers in Southern Ptolemaic Egypt", 77-89 (especially p. 88).

136 Winter, Untersuchungen, 19, 67. 
Graeco-Roman period. ${ }^{137}$ Those of the New Kingdom lack an overall schema and appear relatively free, although they are not undisciplined or random. In comparison, the Graeco-Roman forms are highly systematized and comprehensive, following much more rigid frameworks. This development had its starting point at least in the Thirtieth Dynasty, perhaps already in the preceding Twenty-ninth Dynasty, but in any case after the first Persian period.

Temples of the last native dynasty embodied the sense of identity of the Egyptian elite. We should assume non-royal involvement in temple building, and Spencer sees in it one of the main reasons that the traditional forms of Egyptian cult places persisted through periods of foreign occupation. ${ }^{138}$ This is also true for the Hellenistic and Roman period. ${ }^{139}$ As hieroglyphic Egyptian and Demotic developed, they hardly took in Greek vocabulary. This does show the commitment to traditional culture. Most relevant evidence, for example from Edfu and Dendera, is a bit later than what is considered here, but it must have had a point of departure within the fourth century BCE.

Ptolemaic temple plans are clearly connected to those of the Thirtieth Dynasty. It seems that a master plan was developed, including important elements like the enclosure wall, the axis, the wabet, the birth house, and the ambulatory around the sanctuary as well as the sequence of halls, corridors, and roomsfeatures that were developed under the last native pharaohs or at least are for the first time attested from the Thirtieth Dynasty. The reasons for this continuity might have been to avoid any break from past principles ${ }^{140}$ and to connect themselves to legitimate rulers-or, on a more practical level, because most temples of the Old to the New Kingdom had long since disappeared, whereas temples of the Thirtieth Dynasty were still standing when the Ptolemies and later the Roman emperors ruled Egypt. This pattern also relates to the fact that in the Thirtieth Dynasty older temples were commonly razed to the ground to build new ones, ideally at a larger scale.

Ptolemy I Soter's name is not attested so far in the huge temple complexes of the Thirtieth Dynasty, discussed at the beginning of this chapter, but the name of his son and successor Ptolemy II is. At Tell Basta, no traces of the Ptolemaic period were known until the copy of the Canopus decree was found in 2004. The Satrap Stele from the area of Buto is another lucky piece of evidence that considerably changed our view of the early Hellenistic period in

137 Baines, "King, Temple, and Cosmos", 31.

138 See Spencer, A Naos of Nekhthorheb, 51; Spencer, "Sustaining Egyptian Culture?", 441-446, for a discussion of the king as the initiator of temple construction.

139 See Minas-Nerpel, "Egyptian temples of the Roman Period".

140 Niederberger, Der Chnumtempel, 122. 
Egypt and Soter's involvement with, and perception by, the native priesthood, as chances of survival often influence our picture. From rather few surviving temple blocks, some stelae and chapels, we know that Ptolemy i Soter followed Alexander in promoting native cults and in supporting the temples, thus fulfilling his role as pharaoh. However, only his successor succeeded in leaving huge temples in Egypt that spring immediately to mind: Athribis, Dendera, Edfu, Kom Ombo, and Philae, to mention the obvious ones. Only under Ptolemy II was the ruler cult established in the Egyptian temples, ${ }^{141}$ but without Ptolemy 1 and the Macedonian dynasty its inauguration would not have been possible. Once again, a royal line was established that would leave in Egypt its massive imprint through temple complexes, often larger than anything which went before. These structures took into account the architectural developments of the last native dynasties of Egypt.

\section{Bibliography}

Abd el-Razik, M. 1984. Die Darstellungen und Texte des Sanktuars Alexander des Großen im Tempel von Luxor. Mainz: Philipp von Zabern.

Abd el-Razik, M. 1968. "Study on Nectanebo Ist in Luxor Temple and Karnak". Mitteilungen des Deutschen Archäologischen Instituts, Abteilung Kairo 23: 156-159.

Arnold, D. 1999. Temples of the Last Pharaohs. New York and Oxford: Oxford University Press.

Ashmawy, A. and D. Raue. 2015. "The Temple of Heliopolis: Excavations 2012-14". Egyptian Archeology 46, 8-11.

Ashmawy, A. and D. Raue. 2017. "Report on the Work of the Egyptian-German Mission at Matariya/ Heliopolis in Spring 2012", online: http://www.heliopolisproject.org/wp -content/uploads/2017/07/2nd-season_Matariya_2012-spring-english.pdf.

Ashmawy, A. et al. 2017. "Report on the Work of the Egyptian-German Mission at Matariya/ Heliopolis in Spring 2014", online: http://www.heliopolisproject.org/wp -content/uploads/2017/07/4th-season_Matariya_2014-spring-english.pdf.

Ashmawy, A., M. Beiersdorf, and D. Raue. 2015, "The Thirtieth Dynasty in the Temple of Heliopolis". Egyptian Archaeology 47, 13-16.

Ashmawy, A., M. Beiersdorf, and D. Raue. 2017. "Report on the Work of the EgyptianGerman Mission at Matariya/ Heliopolis in Spring 2015", online: http://www.heliopolisproject.org/wp-content/uploads/2017/o7/5th-season_ Matariya_2015-spring-english.pdf 
Assmann, J. 2000. Herrschaft und Heil. Politische Theologie in Altägypten, Israel und Europa. München: Carl Hanser.

Assmann, J. 1997a. Moses the Egyptian. The Memory of Egypt in Western Monotheism. Cambridge, MA and London: Harvard University Press.

Assmann, J. 1997b. Das kulturelle Gedächtnis. Schrift, Erinnerung und politische Identität in frühen Hochkulturen. München: Beck.

Assmann, J. 1992. "Der Tempel der ägyptischen Spätzeit als Kanonisierung der kulturellen Identität" in The Heritage of Ancient Egypt. Studies in Honour of Erik Iversen, edited by J. Osing and E.K. Nielsen, 9-25. Copenhagen: Museum Tusculanum.

Baines, J. 2011. "Presenting and Discussing Deities in New Kingdom and Third Intermediate Period Egypt" in Reconsidering the Concept of Revolutionary Monotheism, edited by B. Pongratz-Leisten, 41-89. Winona Lake, Indiana: Eisenbrauns.

Baines, J. 1997. "Temples as Symbols, Guarantors, and Participants in Egyptian Civilization" in The Temple in Ancient Egypt. New Discoveries and Recent Research, edited by S. Quirke, 216-241. London: British Museum Press.

Baines, J. 1994. "King, Temple, and Cosmos: An Earlier Model for Framing Columns in the Temple Scenes of the Graeco-Roman Period" in Aspekte spätägyptischer Kultur. Festschrift für Erich Winter zum 65. Geburtstag, edited by M. Minas and J. Zeidler, 23-33. Mainz: Philipp von Zabern.

Barguet, P. 1962. Le temple d'Amon-Rê à Karnak. Essai d'exégèse. Le Caire: Institut Français d'Archéologie Orientale.

Beckerath, J. von. 1999. Handbuch der ägyptischen Königsnamen ${ }^{2}$. Mainz: Philipp von Zabern.

Bell, L. 1997. "The New Kingdom 〈Divine) Temple: The Example of Luxor" in Temples of Ancient Egypt, edited by B.E. Shafer, 127-184. London and New York: Tauris.

Bell, L. 1985. "Luxor Temple and the Cult of the Royal Ka”. Journal of Near Eastern Studies 44: 251-294.

Bianchi, R.S. 1984. "Sebennytos" in Lexikon der Ägyptologie V, edited by W. Helck and W. Westendorf, 766-767. Wiesbaden: Harrassowitz.

Bickel, S. 1998. "Die Dekoration des Tempeltores unter Alexander IV. und der Südwand unter Augustus" in Die Dekoration des Chnumtemples auf Elephantine durch Nektanebos II, edited by H. Jenni, 115-159. Mainz: Philipp von Zabern.

Blackman, A.M. and H.W. Fairman. 1942. "The Myth of Horus at Edfu-II". Journal of Egyptian Archaeology 28: 32-38.

Blöbaum, A.I. 2006. "Denn ich bin ein König, der die Maat liebt". Herrscherlegitimation im spätzeitlichen Ägypten. Eine vergleichende Untersuchung der Phraseologie in den offiziellen Königsinschriften vom Beginn der 25. Dynastie bis zum Ende der makedonischen Herrschaft. Aachen: Shaker.

Bomhard, A.-S. von. 2012. The Decree of Saï: The Stelae of Thonis-Heracleion and Naucratis. Oxford: Oxford Centre for Maritime Archaeology. 
Bomhard, A.-S. von. 2008. The Naos of the Decades. Oxford: Oxford Centre for Maritime Archaeology.

Bosch-Puche, F. and J. Moje. 2015. “Alexander the Great's Name in Contemporary Demotic Sources". Journal of Egyptian Archaeology 101: 340-348.

Bosch-Puche, F. 2014. "The Egyptian Royal Titulary of Alexander the Great, II: Personal Name, Empty Cartouches, Final Remarks, and Appendix". Journal of Egyptian Archaeology 99: 89-110.

Bosch-Puche, F. 2013. "The Egyptian Royal Titulary of Alexander the Great, I: Horus, Two Ladies, Golden Horus, and Throne Names". Journal of Egyptian Archaeology 99: 131-154.

Bosch-Puche, F. 2012. "Alejandro Magno y los cultos a animales sagrados en Egipto". Aula Orientalis 30: 243-277.

Burstein, S.M. 1991. "Pharaoh Alexander. A Scholarly Myth." Ancient Society 22: 139-145 (reprinted in: S.M. Burstein. 1995. Graeco-Africana. Studies in the History of Greek Relations with Egypt and Nubia, 53-61. New Rochelle, NY: Caratzas).

Cabrol, A. 2001. Les voies processionnelles de Thèbes. Leuven: Peeters.

Carrez-Maratray, J.-Y. 1999. Péluse et l'angle oriental du delta Egyptien aux époques grecque, romaine et byzantine. Le Caire: Institut Français d'Archéologie Orientale.

Caßor-Pfeiffer, S. 2008a. "Zur Reflexion ptolemäischer Geschichte in den ägyptischen Tempeln aus der Zeit Ptolemaios IX. Philometor II./Soter II. und Ptolemaios X. Alexander I. (116-80 v.Chr.). Teil 1: die Bau- und Dekorationstätigkeit”. Journal of Egyptian History 1 (1): 21-77.

Caßor-Pfeiffer, S. 2008b. "Zur Reflexion ptolemäischer Geschichte in den ägyptischen Tempeln aus der Zeit Ptolemaios IX. Philometor II./Soter II. und Ptolemaios X. Alexander I. (116-8o v.Chr.). Teil 2: Kleopatra III. und Kleopatra Berenike III. im Spiegel der Tempelreliefs". Journal of Egyptian History 1 (2): $235^{-265}$.

Chauveau, M. 2006. "L'Égypte en transition: des Perses aux Macédoniens" in La transition entre l'empire achéménide et les royaumes héllénistiques (vers 350-30o av. J.-C.). Actes du colloque organisé au Collège de France par la “Chaire d'Histoire et Civilisation du Monde Achéménide et de l'Empire d'Alexandre" et le "Réseau International d'Études et de Recherches Achéménides" (GDR 2538 CNRS), 22-23 novembre 2004, edited by P. Briant, 75-404. Paris: de Boccard.

Cherpion, N. et al. 2007. Le tombeau de Pétosiris à Touna el-Gebel, relevéphotographique. Le Caire: Institut Français d'Archéologie Orientale.

Coppens, F. 2007. The Wabet. Tradition and Innovation in the Temples of the Ptolemaic and Roman Period. Prague: Czech Institute of Egyptology, Charles University.

Daumas, F. 1958. Les mammisis d'Égypte et de Nubie. Paris: La Société.

Depuydt, F. 1989. Archaeological-topographical Surveying of Elkab and Surroundings. Bruxelles: Fondation Egyptologique Reine Élisabeth.

Derchain, P. 1961. Zwei Kapellen des Ptolemäus I. Soter in Hildesheim. Hildesheim: August Lax. 
Dietze, G. 2000. "Temples and Soldiers in Southern Ptolemaic Egypt. Some Epigraphic Evidence" in Politics, Administration and Society in the Hellenistic and Roman World. Proceedings of the International Colloquium, Bertinoro 19-24 July 1997, edited by L. Mooren, 77-89. Leuven: Peeters.

Dowden, K. 2008. "Pseudo-Callisthenes: Alexander Romance" in Collected Ancient Greek Novels ${ }^{2}$, edited by B.P. Reardon, 650-735. Berkeley and London: University of California Press.

Falck, M. von. 2010. "Beiträge zur Geschichte des Horus-Tempels von Edfu. Ein Fund wiederverwendeter Blockfragmente im großen Hof" in Edfu: Materialien und Studien, edited by D. Kurth and W. Waitkus, 51-63. Gladbeck: PeWe.

Fauerbach, U. 2009. "The Creation of an Egyptian Capital” in 7. Ägyptologische Tempeltagung: Structuring Religion, edited by R. Preys, 95-111. Wiesbaden: Harrassowitz.

Favard-Meeks, C. 2003. "Les constructions de Nectanébo II à Behbeit el-Hagara" in Es werde niedergelegt als Schriftstück: Festschrift für Hartwig Altenmüller zum 65. Geburtstag, edited by N. Kloth et al., 97-108. Hamburg: Buske.

Favard-Meeks, C. 2002. "The Present State of the Site of Behbeit el-Hagar". British Museum Studies in Ancient Egypt and Sudan 3: 31-41.

Favard-Meeks, C. 2001. "Behbeit el-Hagar" in The Oxford Encyclopedia of Ancient Egypt I, edited by D.B. Redford, 174-175. New York: Oxford University Press.

Favard-Meeks, C. 1997. "The Temple of Behbeit El-Hagara" in The Temple in Ancient Egypt. New Discoveries and Recent Research, edited by S. Quirke, 102-11. London: British Museum Press.

Favard-Meeks, C. 1991. Le temple de Behbeit el-Hagara. Essai de reconstitution et d'interprétation. Hamburg: Buske.

Finnestad, R.B. 1997. "Temples of the Ptolemaic and Roman Periods: Ancient Traditions in New Contexts" in Temples of Ancient Egypt, edited by B.E. Shafer, 185-237. London: I.B. Tauris.

Finnestad, R.B. 1985. Image of the World and Symbol of the Creator. On the Cosmological and Iconological Values of the Temple of Edfu. Wiesbaden: Harrassowitz.

Fissolo, J.-L. 2011. "Isis de Philae". Egypte, Afrique et Orient 6o: 3-16.

Gabra, G. 2012. "Ein vergessener Naos Nektanebos I. in Alt-Kairo". Studien zur Altägyptischen Kultur 41: 137-138.

Gauger, J.-D. 2002. "Der 'Traum des Nektanebos'-Die griechische Fassung” in Apokalyptik und Ägypten. Eine kritische Analyse der relevanten Texte aus dem griechisch-römischen Ägypten, edited by A. Balsius and B.U. Schipper, 189-219. Leuven: Peeters.

Goldbrunner, L. 2004. Buchis. Eine Untersuchung zur Theologie des heiligen Stieres in Theben zur griechisch-römischen Zeit. Turnhout: Brepols.

Gomaà, F. 1986. "Tell el-Moqdam" in Lexikon der Ägyptologie IV, edited by W. Helck and W. Westendorf, 351-352. Wiesbaden: Harrassowitz. 
Gomaà, F. 1984. "Saft el-Henna" in Lexikon der Ägyptologie IV, edited by W. Helck and W. Westendorf, 351-352. Wiesbaden: Harrassowitz.

Goddio, F. and M. Clauss 2006. Egypt's Sunken Treasures. Munich and London: Prestel. Graefe, E. 1993. 'Die Deutung der sogenannten 'Opfergaben' der Ritualszenen ägyptischer Tempel als 'Schriftzeichen' " in Ritual and Sacrifice in the Ancient Near East: Proceedings of the International Conference Organized by the KU Leuven from the $17^{\text {th }}$ to the 2oth of April 1991, edited by J. Quaegebeur, 143-156. OLA 55. Leuven: Peeters.

Grallert, S. 2001. Bauen-Stiften-Weihen. Ägyptische Bau- und Restaurierungsinschriften von den Anfängen bis zur 3o. Dynastie. Berlin: Achet.

Grenier, J.-C. 2003. "Remarques sur les datations et titulatures de trois steles romaines du Bucheum" Bulletin de l'Institut Français d'Archéologie Orientale 103: 267-279.

Griffith, F.Ll. 189o. Mound of the Jew and the City of Onias: Belbeis, Samanood, Abusir, Tukh El Karmus. 1887. The Antiquities of Tell el Yahûdîyeh, and Miscellaneous Work in Lower Egypt During the Years 1887-1888. London: Egypt Exploration fund.

Habachi, L. 1956. "Notes on the Delta Hermopolis, Capital of the xvth nome of Lower Egypt". Annales du Service des Antiquités de l'Égypte 53: 441-480.

Haeny, G. 1985. "A Short Architectural History of Philae". Bulletin de l'Institut Français d'Archéologie Orientale 85: 197-233.

Hoffmann, F. 2007. "Der Trug des Nektanebos" in Anthologie der demotischen Literatur edited by F. Hoffmann and J.F. Quack, $165^{-166}$ and 348-349. Berlin: LIT.

Hölbl, G. 2004. Altägypten im Römischen Reich II. Die Tempel des römischen Nubien. Mainz: Philipp von Zabern.

Hölbl, G. 2001. A history of the Ptolemaic Empire. London: Routledge.

Hölbl, G. 2000. Altägypten im Römischen Reich I. Der römische Pharao und seine Tempel. Mainz: Philipp von Zabern.

Huß, W. 1994. Der makedonische König und die ägyptischen Priester. Studien zur Geschichte des ptolemaiischen Ägypten. Stuttgart: Steiner.

Jansen-Winkeln, K. 2000. "Die Fremdherrschaften in Ägypten im 1. Jahrtausend v. Chr." Orientalia 69: 1-20.

Jasnow, R. 1997. "The Greek Alexander Romance and Demotic Egyptian Literature". Journal of Near Eastern Studies 56: 95-103.

Jenni, H. 1998. Die Dekoration des Chnumtempels auf Elephantine durch Nektanebos II. Mainz: Philipp von Zabern.

Kahl, J. 2002. "Zu den Namen spätzeitlicher Usurpatoren, Fremdherrscher, Gegen- und Lokalkönige". Zeitschrift für ägyptische Sprache und Altertumskunde 129: 31-42.

Kamal, A. 1904-1905. Stèles ptolémaiques et romaines. Catalogue général des antiquités Égyptiennes du Musée du Caire, nos. 22001-22208, 2 vol., Le Caire: Institut Français d'Archéologie Orientale.

Karig, J.S. 1962. "Einige Bemerkungen zu den ptolemäischen Reliefs in Hildesheim". Zeitschrift für ägyptische Sprache und Altertumskunde 88: 17-24. 
Kessler, D. 2001. "Hermopolis" in The Oxford Encyclopedia of Ancient Egypt II, edited by D.B. Redford, 94-97. New York: Oxford University Press.

Kessler, D. 1998. Tuna el-Gebel II. Die Paviankultkammer G-C-C-2. Hildesheim: Gerstenberg.

Kessler, D. 1989. Die heiligen Tiere und der König I. Beiträge zu Organisation, Kult und Theologie der spätzeitlichen Tierfriedhöfe. Wiesbaden: Harrassowitz.

Kienitz, F.K. 1953. Die politische Geschichte Ägyptens vom 7. bis zum 4. Jahrhundert vor der Zeitenwende. Berlin: Akademie-Verlag.

Klotz, D. 2011. "A Naos of Nectanebo I from the White Monastery Church (Sohag)". Göttinger Miszellen 229: 37-52.

Klotz, D. 2010. "Two Overlooked Oracles". Journal of Egyptian Archaeology 96: 247-254. Kockelmann, H. 2011. "Birth house (Mammisi)" in UCLA Encyclopedia of Egyptology edited by W. Wendrich. Los Angeles. http://escholarship.org/uc/item/8xj4koww

Ladynin, I.A. 2014. "The Argeadai Building Program in Egypt in the Framework of Dynasties' XxIX-Xxx Temple Building" in Alexander the Great and Egypt. History, Art, Tradition. Warschau/Breslau, 18./19. Nov. 2011, edited by V. Grieb et al., Philippika 75, 221-240. Wiesbaden: Harrassowitz.

Ladynin, I.A. 2013. "Late Dynastic Period" in UCLA Encyclopedia of Egyptology, edited by W. Wendrich. Los Angeles. http://escholarship.org/uc/item/2zg136m8

Leclant, J. and G. Clerc. 1987. "Fouilles et travaux en Égypte et au Soudan, 1985-1986". Orientalia 56: 292-389.

Leclant, J. and G. Clerc. 1986. "Fouilles et travaux en Égypte et au Soudan, 1984-1985". Orientalia 55: 236-319.

Leclère, F. 2008. Les villes de basse Égypte au Ier millénaire av. J.-C. Le Caire: Institut Français d'Archéologie Orientale.

Lefebvre, G. 1923/24. Le tombeau de Petosiris I-III. Le Caire: Institut Français d'Archéologie Orientale.

Leitz, C. 1995. Altägyptische Sternuhren. Leuven: Peeters.

Lembke, K. 2010. "The Petosiris-Necropolis of Tuna el-Gebel" in Tradition and Transformation. Egypt under Roman Rule. Proceedings of the International Conference, Hildesheim, 3-6 July 2008, edited by K. Lembke, M. Minas-Nerpel, and S. Pfeiffer, 231254. Leiden and Boston: Brill.

Lichtheim, M. 1980. Ancient Egyptian Literature III: The Late Period. Berkeley and Los Angeles: University of California Press.

Limme, L.J.H. 2001. "Elkab" in The Oxford Encyclopedia of Ancient Egypt I, edited by D.B. Redford, 467-469. New York: Oxford University Press.

Locher, J. 1999. Topographie und Geschichte der Region am ersten Nilkatarakt in griechisch-römischer Zeit. Stuttgart and Leipzig: Teubner.

McKenzie, J. 2007. The Architecture of Alexandria and Egypt c. 300 BC to AD 700. New Haven and London: Yale University Press. 
Meulenaere, H. de. 1986. “Un général du Delta, gouverneur de la Haute Égypte” Chronique d'Égypte 61: 203-210.

Meulenaere, H. de. 1982a. "Naukratis" in Lexikon der Ägyptologie, edited by W. Helck and W. Westendorf, 36o-361. Wiesbaden: Harrassowitz.

Meulenaere, H. de. 1982b. "Isis et Mout du Mammisi" in Studia Paulo Naster oblata II. Orientalia antiqua, edited by J. Quaegebeur, 25-29. Leuven: Peeters.

Minas-Nerpel, M. (in press for 2018-19). "Ptolemaic Queens as Ritualists and Recipients of Cults: The Cases of Arsinoe II and Berenike II". Submitted to Ancient Society.

Minas-Nerpel, M. 2012. "Egyptian Temples of the Roman Period" in The Oxford Handbook of Roman Egypt, edited by C. Riggs. Oxford: Oxford University Press.

Minas, M. 2000. Die hieroglyphischen Ahnenreihen der ptolemäischen Könige. Ein Vergleich mit den Titeln der eponymen Priester in den demotischen und griechischen Papyri. Mainz: Philipp von Zabern.

Minas, M. 1997. “Die Dekorationstätigkeit von Ptolemaios vi. Philometor and Ptolemaios VIII. Euergetes II. an ägyptischen Tempeln, Teil 2". Orientalia Lovaniensia Periodica 28: 87-121.

Minas, M. 1996. "Die Dekorationstätigkeit von Ptolemaios vi. Philometor and Ptolemaios VIII. Euergetes II. an ägyptischen Tempeln, Teil 1". Orientalia Lovaniensia Periodica $27: 51-78$.

Möller, A. 2000. Naukratis. Trade in Archaic Greece. Oxford: Oxford University Press.

Mond, R. and O.H. Myers. 1935, The Bucheum. New York: Alma Egan Hyatt Foundation.

Myśliwiec, K. 2000. The Twilight of Ancient Egypt: The First Millennium BCE. Ithaca, NY: Cornell University Press.

Niederberger, W. 1999. Der Chnumtempel Nektanebos II. Architektur und baugeschichtliche Einordnung. Mainz: Philipp von Zabern.

Patanè, M. 2007. Marginalia. Genève: Tellus Nostra.

Pfeiffer, S. 2014. "Alexander der Große in Ägypten: Überlegungen zur Frage seiner pharaonischen Legitimation" in Alexander the Great and Egypt. History, Art, Tradition. Warschau/Breslau, 18./19. Nov. 20n, edited by V. Grieb et al., Philippika 75, 89-106. Wiesbaden: Harrassowitz.

Pfeiffer, S. 2010. "Naukratis, Heracleion-Thonis and Alexandria: Remarks on the Presence and Trade Activities of Greeks in the North-west Delta from the Seventh Century $\mathrm{BC}$ to the End of the Fourth Century BC" in Alexandria and the North-western Delta: Joint Conference Proceedings of Alexandria: 'City and Harbour' (Oxford 2004) and 'The Trade and Topography of Egypt's North-west Delta, 8th Century Bc to 8th Century $A D^{\prime}$ (Berlin 2006), edited by D. Robinson and W. Andrew Wilson, 15-24. Oxford: School of Archaeology, University of Oxford.

Pfeiffer, S. 2008a. "The God Serapis, his Cult and the Beginnings of the Ruler Cult in Ptolemaic Egypt" in Ptolemy II Philadelphus and his World, edited by P. McKechnie and P. Guillaume, 387-408. Leiden and Boston: Brill. 
Pfeiffer, S. 2008b. Herrscher- und Dynastiekulte im Ptolemäerreich. Systematik und Einordnung der Kultformen. München: Beck.

Pfeiffer, S. 2004. Das Dekret von Kanopos (238 v. Chr.). Kommentar und historische Auswertung eines dreisprachigen Synodaldekretes der ägyptischen Priester zu Ehren Ptolemaios' III. und seiner Familie. München and Leipzig: Saur.

Phillips, J.P. 2002. The Columns of Egypt. Manchester: Peartree.

Quack, J.F. 2009. "Die Theologisierung der bürokratischen Norm. Zur Baubeschreibung in Edfu im Vergleich zum Buch vom Tempel” in 7. Ägyptologische Tempeltagung: Structuring Religion, Leuven, 28. September-1. Oktober 2005, edited by R. Preys, 221229. Wiesbaden: Harrassowitz.

Raue, D. 1999. Heliopolis und das Haus des Re. Eine Prosopographie und ein Toponym im Neuen Reich, ADAIK 16. Berlin: Achet.

Ricke, H. 1960. Die Tempel Nektanebos' II. in Elephantine. Schweizerisches Institut für ägyptische Bauforschung und Altertumskunde.

Roeder, G. 1954. "Zwei hieroglyphische Inschriften aus Hermopolis (Oberägypten)". Annales du Service des Antiquités de l'Égypte 52: 315-442.

Rondot, V. 1989, “Une monographie bubastite". Bulletin de l'Institut Français d'Archéologie Orientale 89: 249-270.

Rosenow, D. 2008a, Das Tempelhaus des Großen Bastet-Tempels in Bubastis. Dissertation zur Erlangung des akademischen Grades doctor philosophiae (Dr. phil.), Humboldt University of Berlin (online: https://edoc.hu-berlin.de/handle/18452/17739)

Rosenow, D. 2008b. "The Great Temple of Bastet at Bubastis". Egyptian Archaeology 32: 11-13.

Rosenow, D. 2006a. "Le sanctuaire de Nectanebo II à Boubastis: état présent, interprétation et reconstitution d' un temple de Basse Époque dans le Delta". Egypte, Afrique et Orient 42: 29-40.

Rosenow, D. 2006b. "The Nekhethorheb Temple" in A Naos of Nekhthorheb from Bubastis. Religious Iconography and Temple Building in the 3oth Dynasty, edited by N.A. Spencer, 43-46. London: British Museum Press.

Rosenow, D. 2003. "Der Nektanebos-Tempel" in Tell Basta: vorläufiger Bericht der XIV. Kampagne edited by C. Tietze, $15^{-133}$. Potsdam: Universität Potsdam.

Ruzicka, S. 2012. Trouble in the West: Egypt and the Persian Empire, 525-332 BCE. Oxford et al.: Oxford University Press.

Ryholt, K. 2002. "Nectanebo's Dream or the Prophecy of Petesis" in Apokalyptik und Ägypten. Eine kritische Analyse der relevanten Texte aus dem griechisch-römischen Ägypten, edited by A. Balsius and B.U. Schipper, 221-241. Leuven: Peeters.

Sayed (el-), R. 1975. Documents relatifs à Sais et ses divinités. Le Caire: Institut Français d'Archéologie Orientale.

Schäfer, D. 2011. Makedonische Pharaonen und hieroglyphische Stelen. Historische Untersuchungen zur Satrapenstele und verwandten Denkmälern. Leuven: Peeters. 
Schäfer, D. 2007. "Alexander der Große. Pharao und Priester" in Ägypten unter fremden Herrschern zwischen persischer Satrapie und römischer Provinz, edited by S. Pfeiffer, 54-74. Frankfurt: Verlag Antike.

Schneider, T. 1998. "Mythos und Zeitgeschichte in der 30. Dynastie. Eine politische Lektüre des 'Mythos von den Götterkönigen'” in Ein ägyptisches Glasperlenspiel. Ägyptologische Beiträge für Erik Hornung aus seinem Schülerkreis, edited by A. Brodbeck, 207-242. Berlin: Mann.

Sethe, K. 1904. Hieroglyphische Urkunden der griechisch-römischen Zeit. Leipzig: Hinrichs.

Spencer, N.A. 2011. "The Egyptian Temple and Settlement at Naukratis". British Museum Studies in Ancient Egypt and Sudan 17: 31-43.

Spencer, N.A. 2010. "Sustaining Egyptian Culture? Non-Royal Initiatives in the Late Period Temple Building" in Egypt in Transition. Social and Religious Development of Egypt in the First Millennium BCE. Proceedings of an International Conference Prague, September 1-4, 2009, edited by L. Bareš, F. Coppens, and K. Smoláriková, 441-490. Prague: Czech Institute of Egyptology, Faculty of Arts, Charles University in Prague. Spencer, N.A. 2006a. A Naos of Nekhthorheb from Bubastis. Religious Iconography and Temple Building in the 3 oth Dynasty. London: British Museum.

Spencer, N.A. 2006b. "Edouard Naville et l' Egypt Exploration Fund: A la découverte des temples de la xxxe dynastie dans le Delta". Egypte: Afrique et Orient 42: 11-18.

Spencer, N.A. 2003. Review of Niederberger, Der Chnumtempel. Journal of Egyptian Archaeology 89: 273-278.

Spencer, N.A. 2000. Sustaining Egyptian Culture. Royal and Private Construction Initiatives in the First Millennium BC. PhD dissertation, University of Cambridge.

Spencer, N.A. 1999. "The temple of Onuris-Shu at Samanud". Egyptian Archaeology 14: 7-9.

Swinnen, W. 1973. "Sur la politique religieuse de Ptolémée Ier" in Les Syncrétismes dans les Religions Grecque et Romaine. Colloque de Strasbourg, 9-11Juin 1971, 113-133. Paris: Presses universitaires de France.

Thiers, C. 1997. "Un naos de Ptolémée II Philadelphe consacré à Sokar". Bulletin de l'Institut Français d'Archéologie Orientale 97: 253-268.

Thomas, R.I. and A. Villing. 2013. "Naukratis Revisited 2012: Integrating New Fieldwork and Old Research" British Museum Studies in Ancient Egypt and Sudan 20: 81-125.

Tietze, C., E.R. Lange, K. Hallof. 2005. "Ein neues Exemplar des Kanopus-Dekrets aus Bubastis" Archiv für Papyrusforschung und verwandte Gebiete 51: 1-30.

Tietze, C. 2001. "Bubastis" in The Oxford Encyclopedia of Ancient Egypt I, edited by D.B. Redford, 208-209. New York: Oxford University Press.

Traunecker, C. 1979. "Essai sur l' histoire de la Xxıx ${ }^{\mathrm{e}}$ Dynastie”. Bulletin de l'Institut Français d'Archéologie Orientale 79: 395-436.

Vassilika, E. 1989. Ptolemaic Philae. Leuven: Peeters. 
Verhoeven, Ursula. 2008. "Neue Tempel für Ägypten. Spuren des Augustus von Dendera bis Dendur" in Augustus-Der Blickvon aussen. Die Wahrnehmung des Kaisers in den Provinzen des Reiches und in den Nachbarstaaten. Akten der internationalen Tagung an der Johannes Gutenberg-Universität Mainz vom 12.-14. Oktober 2006, edited by D. Kreikenbom, 229-248. Wiesbaden: Harrassowitz.

Virenque, H. 2006. "Les quatre Naos de Saft el-Henneh: un rempart théologique construit par Nectanebo Ier dans le Delta oriental”. Egypte: Afrique et Orient 42: 19-28.

Vittmann, G. 2003. Ägypten und die Fremden im ersten vorchristlichen Jahrtausend. Mainz: Philipp von Zabern.

Waitkus, W. 2008. Untersuchungen zu Kult und Funktion des Luxortempels. Gladbeck: PeWe.

Wildung, D. 1977. Imhotep und Amenhotep. Gottwerdung im alten Ägypten. München und Berlin: Deutscher Kunstverlag.

Winter, E. 2005. "Alexander der Große als Pharao in ägyptischen Tempeln" in Ägypten Griechenland Rom. Abwehr und Berührung. Städelsches Kunstinstitut und Städtische Galerie, 26. November 2005-26. Februar 2006, edited by H. Beck et al., 204-215. Tübingen: Ernst Wasmuth.

Winter, E. 1982. "Philae" in Lexikon der Ägyptologie IV, edited by W. Helck and W. Westendorf, 1022-1028. Wiesbaden: Harrassowitz.

Winter, E. 1968. Untersuchungen zu den ägyptischen Tempelreliefs der griechisch-römischen Zeit. Wien: H. Böhlau Nachf.

Yoyotte, J. 2013. Histoire, géographie et religion de l'Égypte ancienne: Opera selecta. Leuven: Peeters.

Yoyotte, J. 2001. "Le second affichage du décret de l' an 2 de Nekhetnebef et la découverte de Thônis-Héracléion". Égypte: Afrique et Orient 24: 25-34.

Yoyotte, J. 1983. “L'Amon de Naukratis". Revue d'Egyptologie 34: 129-136.

Žabkar, L.V. 1988. Hymns to Isis in Her Temple at Philae. Hanover and London: University Press of New England.

Zivie, A.-P. 1970. “A propos du toponyme dbt mentionné dans les Textes des Pyramides". Revue d'Égyptologie 22: 206-207. 